\title{
Review \\ State of the Art of Technologies in Adaptive Dynamic Building Envelopes (ADBEs)
}

\author{
Negar Mohtashami ${ }^{1, *}$, Nico Fuchs ${ }^{1}{ }^{1}$, Maria Fotopoulou ${ }^{2}\left(\mathbb{D}\right.$, Panagiotis Drosatos $^{2}$, Rita Streblow ${ }^{1}(\mathbb{D}$, \\ Tanja Osterhage ${ }^{1}$ and Dirk Müller ${ }^{1}$ \\ 1 Institute for Energy Efficient Buildings and Indoor Climate, RWTH Aachen University, \\ 52074 Aachen, Germany; nico.fuchs@eonerc.rwth-aachen.de (N.F.); rstreblow@eonerc.rwth-aachen.de (R.S.); \\ tosterhage@eonerc.rwth-aachen.de (T.O.); dmueller@eonerc.rwth-aachen.de (D.M.) \\ 2 Center for Research and Technology Hellas-CERTH, 15125 Marousi, Greece; fotopoulou@certh.gr (M.F.); \\ drosatos@certh.gr (P.D.) \\ * Correspondence: negar.mohtashami@eonerc.rwth-aachen.de
}

\section{check for}

updates

Citation: Mohtashami, N.; Fuchs, N.; Fotopoulou, M.; Drosatos, P.;

Streblow, R.; Osterhage, T.; Müller, D. State of the Art of Technologies in Adaptive Dynamic Building Envelopes (ADBEs). Energies 2022, 15, 829. https://doi.org/10.3390/ en15030829

Academic Editors:

Iakovos T. Michailidis, Hu Du and Simone Baldi

Received: 15 December 2021

Accepted: 19 January 2022

Published: 24 January 2022

Publisher's Note: MDPI stays neutral with regard to jurisdictional claims in published maps and institutional affiliations.

Copyright: (c) 2022 by the authors. Licensee MDPI, Basel, Switzerland. This article is an open access article distributed under the terms and conditions of the Creative Commons Attribution (CC BY) license (https:// creativecommons.org/licenses/by/ $4.0 /)$.

\begin{abstract}
The design of adaptive façades as complex systems that dynamically respond to weather conditions and occupants' demands is rapidly increasing in modern constructions since they are highly energy efficient. Adaptive Dynamic Building Envelopes (ADBEs) exploit the benefits of technologies that manage the energy and mass transfer between building and outdoor environments actively and selectively. There is a wide range of technologies used in the design of ADBEs that differ from one another in terms of user controllability and the level of how active or passive their technologies are. This paper provides a systematic search in literature on the technologies devised in the ADBEs, specifying the most prevalent practices, and highlights the most cutting-edge research approximations. The analysis shows more than half of the studies use photovoltaics (PVs) in their design. Using mechanical ventilation and heat pumps were the next popular choices. Moreover, approximately half of the studies were carried out using simulation methods alone, whereas only $13 \%$ of studies couple simulations with experimental work. This highlights a clear gap in coupling digital modeling and simulation software with practical field testing and successful mass production.
\end{abstract}

Keywords: Adaptive Dynamic Building Envelopes; adaptive façade; energy efficiency; active and passive systems

\section{Introduction}

Buildings consume a share of approximately $30-40 \%$ of the primary energy throughout the world and make up for nearly one-third of the greenhouse gas emissions (GHG) [1] The European Union policies on building level are moving toward an integrated approach considering energy, costs, and environmental aspects together with enhancement of indoor comfort. In 2018, the European Parliament legislated for an improved 2030 target of reducing domestic greenhouse gas emission by at least $40 \%$ [2]. The European Commission and the Horizon 2020 program promote affordable technologies and solutions at building and district levels to ensure a shift toward the decarbonization of the existing building market [3]. An effective solution to shift toward decarbonization in the built environment is the improvement of building envelopes. As a result, a growing number of incentives, such as COST Action TU 1403 on adaptive facades [4], encourage specialized academic research to improve the building envelope with the help of different technologies. Furthermore, the International Energy Agency Solar Heating and Cooling research network (IEA SHC) amends research and practical approaches toward more adaptive façades by initiating two task forces. Task 56 [5] focuses on simulation, laboratory testing, and onsite monitoring of Building Integrated Solar Envelope Systems, while Task 60 [6] provides principals for the system design of photovoltaic thermal hybrid solar collectors (PVT collectors) and explores the performance of existing technologies. 
The building envelope is the interface between indoor and outdoor environments and is mainly responsible for mitigating harsh weather conditions outside [7]. Regardless of how the envelope is designed, it is not possible to avoid undesirable heat, mass, and humidity transfer between indoor and outdoor spaces, mainly because of temperature and humidity differences during most times of the year. This includes heat conduction and radiation exchange from the envelope surfaces, and direct air exchange through ventilation and leakage [8]. The internal environmental condition is usually maintained through a mix of active and passive measures that can be incorporated into the envelope structure $[9,10]$. Passive measures usually include materials and window constructions that do not require direct energy to perform. The active measures refer to the Heating, Cooling and Air Conditioning systems (HVAC), which transform some means of energy into heating, cooling, or humidification measures. The combination of active and passive systems enables the envelope to dynamically adapt to the outdoor weather conditions more resiliently, which results in improved energy efficiency and occupant thermal comfort. These so-called Adaptive Dynamic Building Envelopes (ADBEs) need to be properly designed in order to lower the heating and cooling loads of the building, either through the use of active technologies, passive technologies, or a combination of both of these technologies.

The passive control of indoor conditions has been a popular intervention by designers throughout history and dates back to the hanging gardens of Babylon. It has mainly consisted of climbing greeneries on walls with cooling and shading effects. This idea had been used in ancient architecture of hot-arid climates where evaporative cooling works most effectively. In modern construction, the same idea was pursued by following the so-called green façade idea, which consisted of climbing plants growing over the walls or on a mesh system attached to the wall [11], and was heavily promoted in North America in 1920s [12]. Other creative passive control systems were double-skin façades in the 1850s, which were widely used in the US, Europe, and Japan [13]. The idea entails a passive façade consisting of layers of glazing and air, where the air could potentially flow freely between the layers [14]. Another passive design solution seeks to improve the thermal properties of the building Trombe wall system [15]. The Trombe wall consists of a high thermal mass material as the base and a glazing layer installed in a small distance from it. This system captures the solar radiation, which then transfers part of it to the interior space through convection. Another feature of the Trombe wall is the circulation of air through its gaps. More specifically, the air circulates in the adjacent room through openings at the lower and upper part of the wall, providing a hot stream of air that helps the thermal comfort. [16].

The use of complex materials in the building envelope revolutionized passive design of the façade. Applying phase change materials (PCM) in the building design began in the mid-1940s [17]. 'Smart materials' as the keywords for such systems are defined as 'embedded technological functions' that have a specific response to ambient changes, exploiting the changing physical properties of the materials [18]. Several studies have implemented PCM, usually in combination with other technologies, and demonstrated that the implementation of PCM in a building's envelope reduces energy demand [19-23]. The efficiency of solutions using PCM ranges widely from 7\% energy consumption reduction to energy-positive buildings, which is mainly due to the specific design and technologies they are coupled with. Kishore et al. [24] couple PCM between two layers of the dynamic insulation material and system (DIMS) and show that combining the two technologies results in a reduction of $15-72 \%$ in annual heat gain and $7-38 \%$ in annual heat loss. $\mathrm{Hu}$ and $\mathrm{Yu}$ [25] draw a similar conclusion with 17-27\% reduction in total energy use of a building in a mild climate based on different thicknesses of PCM layer. On a higher level, Favoino et al. [26] manage to combine PCM with other technologies and exploit the ability of them to change their thermo-physical behavior and to face several contrasting boundary conditions and therefore act as an energy-positive envelope.

The trend of only using passive systems for an adaptive response to environmental conditions has evolved since the mid-20th century, where the concept of installing photovoltaics (PVs) on the façade was introduced. Although the integration of active systems 
in the façade had practically started before that, a clear definition was only introduced in a 2003 project report, specifically referring to mechanical devices that utilize renewable energy to produce electricity, heating, and cooling energy [27]. Powerful example of such devices are building-integrated photovoltaics (BIPV). BIPVs are PV panels that are installed on the envelope of a building, replace the traditional envelope construction material, and produce electricity for the building. Extracting heat, in addition to electricity, is what distinguishes a building-integrated photovoltaic-thermal collector (BIPV/T) from a conventional BIPV. Arkar et al. [24] use PCM for the design and evaluation of the energy performance in a prototype of a building-integrated semi-transparent photovoltaic-thermal façade structure (BISPV/T). Some studies combine BIPV/T, heat pumps, and PCM on façades of buildings [28] for finding creative low-energy solutions, which will be introduced in more detail in the following sections.

Depending on its function and installation area, the building envelope usually refers to the combination of walls, roof, floor, and the other components that are entailed. The walls make up for the main area of the envelope. Therefore, their impact on regulating the internal environmental conditions is significant, and researchers show a specific interest in working on them. Traditionally, it had been a common practice that the building envelope be solely considered as the passive element that is responsible for maintaining indoor thermal conditions, while the HVAC systems have been installed inside the room separately. It is believed that with proper envelope design, a $20 \%$ to $50 \%$ reduction in total energy consumption can be achieved [29]. However, there is a wide range of different HVAC technologies suitable to incorporate in an ADBE design, which might confuse the designers when making the right selection. There have been recent reviews of passive and active envelope technologies, investigated from morphological [30,31], occupant behavior [32], structural characterization $[33,34]$, and terminology [35] points of view. The purpose of this review paper is to cover the aforementioned literature gap by providing an inclusive and thorough review of the state of the art of technologies utilized in ADBEs, thus expanding the scope of [30-35]. In this regard, the motivation of this review is to:

- Provide a state-of-the-art review that shows which kind of active or passive technologies are more frequently used in ADBE design and with which other technologies they are coupled: no state-of-the-art review has been carried out to classify the different technologies, show the abundancy of each type of active or passive technologies used in the ADBE design, and define their targets and objectives.

- Provide a clear distinguish between ADBE technologies that use active or passive systems: there have been many terminologies used for adaptive dynamic building envelopes that differ in terms of their level of active or passiveness of their technologies and their user controllability. Therefore, a clear distinction between these technologies is required.

The paper consists of seven main sections. Section 1 investigates the development of passive systems throughout history and how they have been coupled with active systems in the past decades resulting in similar concepts with different terminologies. Section 2 introduces different technologies that ADBEs usually entail. After that, ADBE typologies are compared to each other according to costs, maturity of the system, etc. Following that, in Section 3, different terminologies of ADBE are compared with one another according to their level of controllability and how active or passive their technologies are. Section 4 investigates the standards and requirements for the design and construction of ADBEs. In Section 5, the results of a systematic literature review of 117 studies are presented, and factors such as scale, different climate zones and prevalent technologies used for the design of ADBEs are discussed. Section 6 draws a roadmap for the future of ADBE systems and highlights the challenges and technical issues involved. Finally, the study is concluded in Section 7 with a summary of the most important points of the literature analysis. 


\section{Technologies and Typologies of ADBEs}

Since the term "ADBE" is newly introduced, the overall ADBE concept is quite abstract and may include a variety of technologies, typologies, etc., depending on their purpose [36]. This section aims to provide a background regarding the main technologies that usually compose an ADBE as well as the main ADBE typologies that can result depending on the combination of technologies.

\subsection{Technologies of ADBEs}

There is a range of technologies that an ADBE can incorporate to enhance a building's energy performance. According to their usage, they can be sorted into four categories, i.e., technologies for energy harvesting, technologies affecting heat transfer, technologies for air conditioning, and technologies for storage systems [37,38]. The purpose of this sub-section is to present and analyze the basic/main technologies of each category.

\subsubsection{Technologies for Energy Harvesting}

In general, energy harvesting can be performed through a variety of Renewable Energy Sources (RES), which have minimal environmental impact [39]. However, when it comes to building envelopes, the options may be limited due to space and weight concerns. In literature, the main (but not the only) source utilized for energy harvesting in buildings is solar radiation [40]. A popular technology for electrical energy harvesting in ADBEs is the BIPV system [41]. This practical technology can be added either on the façade of a building, where it may cover a large area, or on its roof, where it may produce power more efficiently due to the tilt angle [42]. In both cases, it produces electrical energy throughout the year, contributing to the self-generation and reduction of additional electricity consumption of the building from the grid [43]. Another popular energy harvesting technology is the solar thermal collector, which collects heat by absorbing solar radiation and is commonly placed on the roof of the building. Water as the circulating medium displaces heat to a separated reservoir that can be used for heating purposes [44]. Furthermore, solar air heater (SAH), which is also powered by solar radiation, can be used for providing heated air for direct use inside the building [45]. However, over the past few years there have been some cases where the ADBE is proposed to harvest wind energy instead of solar energy, which is achieved through the implementation of Wind Turbines (WTs) [46].

\subsubsection{Technologies Affecting Heat Transfer}

The heat transfer between buildings and ambient environments affects thermal comfort inside buildings, especially in cases of extreme weather conditions. The use of insulation materials is a widespread, cost-efficient, and passive component for ADBEs that influences heat transfer. There is a wide range of insulation materials that differ from one another, mainly in their costs and embodied energy rather than their thermal conductivity. Therefore, it is usually a cost-carbon trade-off when choosing an insulation material to implement in the façade design. On a more advanced level, the insulation effect is produced by absence of materials, in form of vacuum insulation. Another, more modern, approach, which is frequently observed in literature, is the incorporation of PCM in ADBEs [47]. These materials have high latent heat capacities and are able to accumulate and release thermal energy during the melting-freezing cycle [48]. PCMs can be both considered as active and passive technologies in buildings, depending on whether they are triggered by a natural phenomenon such as solar radiation or by an external energy source such as electricity.

When it comes to the windows of the façades, heat transfer is related to the solar radiation entering the building. In this case, the heat transfer is reduced by controlling the sunblinds in front of the windows [49]. The heat transfer can also be reduced by implementing BISPV/T panels on the windows, the semi-transparency of which reduces the solar irradiation entering the building. 


\subsubsection{Technologies for Air Conditioning}

Air conditioning systems control the temperature and/or the flow of the air inside the buildings. For this purpose, the most well-known technologies are heat pumps [50]. Heat pumps transfer thermal energy in the opposite direction of heat transfer, through the refrigeration cycle, and may be air-sourced, water-sourced, or ground-sourced depending on the heat source upon which they rely [51]. Small-scale heat pump units are usually implemented in the façades of buildings and are capable of heating/cooling adequately a room or a zone of the building. Another cost-efficient technology for air conditioning is the mechanical ventilator [52], which circulates the air in the building and may also be coupled with a heat exchanging unit to recover some part of the heating or cooling energy [53]. Decentralized mechanical ventilation units can, in general, be placed in single rooms. However, in an ADBE (including appropriately designed pipes, etc.) one central mechanical ventilation unit may supply several rooms. Furthermore, thermoelectric walls are considered to be a solution for the air conditioning of a building, although they are not so frequently observed in literature. Thermoelectric walls convert electricity to heat through different types of semi-conductors (Peltier effect) and may be used to cool or heat a room [54]. Another solution, relevant to building skins, is the use of radiant heating/cooling systems. This is a category of HVAC technologies that can exchange heat through both convection and radiation with the spaces that they are designed to heat or cool. These systems have gained acceptance as HVAC solutions due to their energy saving potential while achieving adequate thermal comfort and maintaining acceptable indoor air quality.

\subsubsection{Storage Systems}

The energy harvested by an ADBE may not be directly consumed, depending on the demand curve of the occupants and the building's operation. Yet, the mismatch between the energy production and demand can be reduced when storage systems are deployed [55]. For the storage of electrical energy, the most popular technology used is the battery energy storage system (BESS), which can be based on lithium, lead-acid, etc. [56]. At this point, it should be noted that BESS are geographically independent, in contrast to the majority of active ADBE elements [57]. On the other hand, for excessive thermal energy, thermal energy storage (TES) technologies can be deployed. This category is comprised of sensible heat storage technologies [58], such as water tanks, and latent heat storage technologies, such as PCM storage units $[59,60]$. It should be noted that since the façades of ADBEs can only support limited weight, only small and light storage systems are usually implemented on them (with small capacity). On the contrary, the common practice is to place the storage units on the top or bottom part of the ADBE. Nonetheless, special attention to safety requirements, in particular fire protection standards, must be met for installation of BESS in south façades.

\subsubsection{Synopsis of ADBE Technologies}

To sum up, the main technologies that compose ADBEs are presented in Table 1. It is noted that there is a variety of technologies related to energy harvesting, heat transfer, air conditioning, and storage. In many cases their base is solar radiation, which is relatively easy to harvest in buildings [40]. Their technologies may be simple and commonly used, such as insulation [61] and solar thermal collectors [44], or advanced and rarely implemented, such as thermoelectric walls [54] and PCM storage units [60]. The purpose of each technology may be related to the building's thermal needs, e.g., heat pumps and sensible heat storage, or electrical needs, e.g., BIPV panels and BESS [62]. Of course, the presented technologies may be combined in a variety of ways, such as energy harvesting coupled with storage [63] or energy harvesting coupled with air conditioning [64], depending on the building's location, operation, etc. 
Table 1. Main technologies for ADBEs [41-60].

\begin{tabular}{|c|c|c|c|c|c|c|}
\hline & Technology & Description & Benefits & Limitations & Base & Purpose \\
\hline \multirow{8}{*}{ 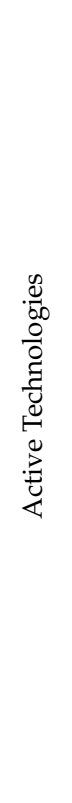 } & BIPV & $\begin{array}{l}\text { Building integrated } \\
\text { photovoltaics }\end{array}$ & Self-generation & $\begin{array}{c}\text { Suitable for areas with } \\
\text { high exposure to } \\
\text { sunlight }\end{array}$ & Solar radiation & Electrical needs \\
\hline & $\begin{array}{l}\text { Solar thermal } \\
\text { collector }\end{array}$ & $\begin{array}{l}\text { Converts solar radiation } \\
\text { to heat }\end{array}$ & $\begin{array}{l}\text { Thermal load } \\
\text { reduction, easy } \\
\text { implementation }\end{array}$ & $\begin{array}{c}\text { Suitable for areas with } \\
\text { high exposure to } \\
\text { sunlight }\end{array}$ & Solar radiation & Thermal needs \\
\hline & SAH & $\begin{array}{l}\text { Converts solar } \\
\text { radiation/heat to heated } \\
\text { air inside the building }\end{array}$ & $\begin{array}{l}\text { Thermal energy } \\
\text { harvesting }\end{array}$ & $\begin{array}{l}\text { Suitable for areas with } \\
\text { high exposure to } \\
\text { sunlight }\end{array}$ & $\begin{array}{l}\text { Solar } \\
\text { radiation/heat }\end{array}$ & Thermal needs \\
\hline & WT & $\begin{array}{l}\text { Converts wind energy to } \\
\text { electricity }\end{array}$ & Self-generation & $\begin{array}{l}\text { Suitable if wind speed is } \\
\text { sufficient, heavy system }\end{array}$ & Wind & Electrical needs \\
\hline & Heat pump & $\begin{array}{l}\text { Transfers heat against } \\
\text { natural temperature } \\
\text { gradient, used for either } \\
\text { heating or cooling }\end{array}$ & $\begin{array}{l}\text { Applicable in any } \\
\text { condition }\end{array}$ & $\begin{array}{l}\text { Not entirely } \\
\text { carbon-neutral }\end{array}$ & $\begin{array}{l}\text { Air-sourced } \\
\text { water-sourced, } \\
\text { ground-sourced }\end{array}$ & Thermal needs \\
\hline & $\begin{array}{l}\text { Mechanical } \\
\text { ventilation }\end{array}$ & $\begin{array}{l}\text { Utilization of fans for the } \\
\text { circulation of air in } \\
\text { buildings }\end{array}$ & $\begin{array}{l}\text { Cost effective } \\
\text { solution, easy } \\
\text { implementation }\end{array}$ & Limited effect & Air & Thermal needs \\
\hline & $\begin{array}{l}\text { Thermoelectric } \\
\text { wall }\end{array}$ & $\begin{array}{l}\text { Utilization of the Peltier } \\
\text { effect for heating/cooling } \\
\text { purposes }\end{array}$ & $\begin{array}{l}\text { Advanced air } \\
\text { conditioning } \\
\text { system }\end{array}$ & $\begin{array}{l}\text { Rarely implemented } \\
\text { technology }\end{array}$ & $\begin{array}{l}\text { Electricity } \\
\text { (Peltier) }\end{array}$ & Thermal needs \\
\hline & BESS & $\begin{array}{c}\text { Lithium-based storage of } \\
\text { electricity }\end{array}$ & $\begin{array}{l}\text { Increase of electrical } \\
\text { self-generation }\end{array}$ & Heavy system & Electricity & Electrical needs \\
\hline \multirow{2}{*}{ 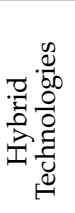 } & PCM & Phase Change Material & $\begin{array}{l}\text { Efficient reduction } \\
\text { of heat transfer }\end{array}$ & $\begin{array}{c}\text { More expensive than } \\
\text { usual insulation, high } \\
\text { embodied energy }\end{array}$ & $\begin{array}{l}\text { High latent heat } \\
\text { capacity }\end{array}$ & Thermal needs \\
\hline & $\begin{array}{l}\text { PCM storage } \\
\text { unit }\end{array}$ & $\begin{array}{c}\text { Storage of thermal energy } \\
\text { using PCM }\end{array}$ & $\begin{array}{l}\text { Advanced storage } \\
\text { system, thermal } \\
\text { load reduction }\end{array}$ & $\begin{array}{l}\text { Rarely implemented } \\
\text { technology }\end{array}$ & PCM & Thermal needs \\
\hline \multirow{3}{*}{ 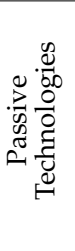 } & Insulation & $\begin{array}{c}\text { Decrease in heat losses } \\
\text { through low thermal } \\
\text { conductivity }\end{array}$ & $\begin{array}{l}\text { Cost-effective } \\
\text { solution, easy } \\
\text { implementation }\end{array}$ & $\begin{array}{l}\text { Only passive } \\
\text { technology }\end{array}$ & $\begin{array}{l}\text { Low thermal } \\
\text { conductivity }\end{array}$ & Thermal needs \\
\hline & $\begin{array}{l}\text { Sensible heat } \\
\text { storage }\end{array}$ & Water-based heat storage & $\begin{array}{l}\text { Efficient mitigation } \\
\text { of thermal needs }\end{array}$ & Heavy system & Water & Thermal needs \\
\hline & Sunblind & Shading for windows & $\begin{array}{l}\text { Cost-effective } \\
\text { solution }\end{array}$ & $\begin{array}{l}\text { Limited effect, only } \\
\text { applicable in windows }\end{array}$ & $\begin{array}{l}\text { Solar radiation, } \\
\text { windows }\end{array}$ & Thermal needs \\
\hline
\end{tabular}

\subsection{Typologies of $A D B E s$}

An ADBE may be designed and implemented with special focus on a certain need of the building, e.g., reduction of heating/cooling loads, improvement of user comfort, or self-generation requirements $[12,65]$. Therefore, an ADBE neither has a standard design nor serves the same purpose. Nevertheless, based on the most frequent configurations, four main typologies of ADBEs are distinguished i.e., water-based, air-based, solid-based, and kinetic [35] As presented in Figure 1. This sub-section aims to highlight the distinctive features of each typology and compare them, considering key parameters.

\subsubsection{Water-Based ADBE}

Water is frequently utilized as a working medium in ADBE design, thanks to its high specific heat capacity, low cost, abundance, and non-toxicity [59,66-70]. There are several options regarding its utilization in the literature [71,72]. This tested-in-time concept has low construction and maintenance costs [73] and allows for heated or cooled water to pass through the pipes efficiently, providing the building with extra thermal insulation in winter or summer, respectively.

Another approach of water-based ADBE is presented in [74,75]. In this case, the construction consists of (a) an outer insulation level, (b) a gap, and (c) the existing external wall. Water is sprayed inside the gap between the outer insulation layer and the existing wall and then evaporated in order to cool the room. The proposed system is mostly implemented for the mitigation of cooling loads during summer and may preserve thermal 
comfort of the occupants, even when the outdoor temperature reaches $40{ }^{\circ} \mathrm{C}$, according to [76]. Using the evaporative cooling effect of water was even common in traditional architecture of hot arid climates such as Iran and Egypt, where the temperature exceeds $40{ }^{\circ} \mathrm{C}$. Furthermore, for cooling purposes, alternative approaches have been developed, including constructions such as water-glazing windows [70]. In this case, water flows between glass layers that separate the outside environment from the building interior, thus reducing the cooling load of the room while allowing sunlight to enter it.
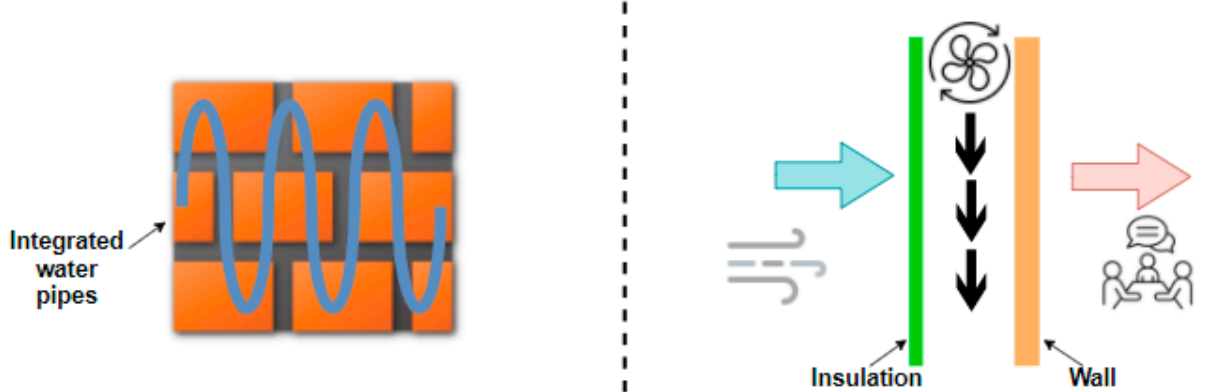

Water-based Air-based

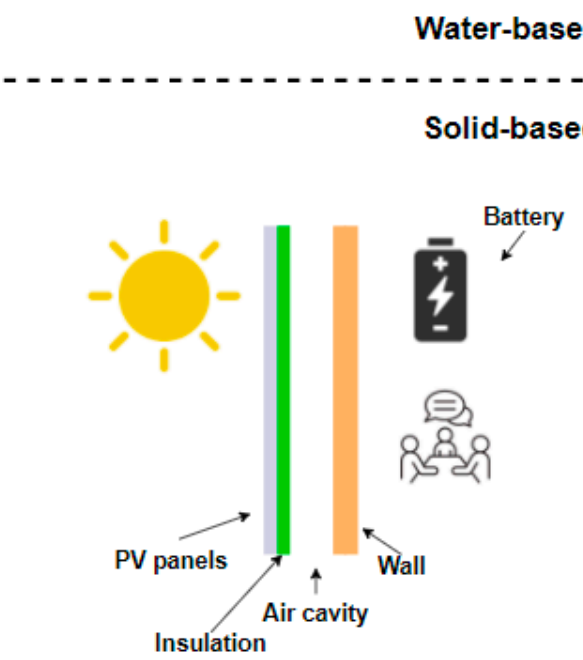

Air-based

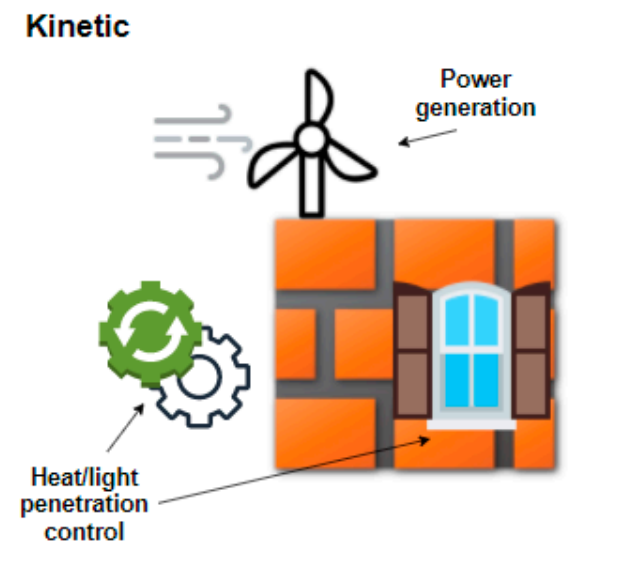

Figure 1. Typologies of ADBEs.

\subsubsection{Air-Based ADBE}

Air-based ADBEs constitute a popular option as they are efficient and can be combined with a variety of technologies. The basic design of an air-based ADBE comprises an insulation layer placed in front of the existing wall's surface, forming an air cavity, as presented in Figure 1. The air cavity provides the building with extra thermal insulation, thus reducing its thermal/cooling loads. Although the cavity can be plain, considering only natural ventilation [77], more advanced options (including mechanical ventilation, and heat recovery) can be adopted. For example, mechanical ventilation with heat recovery in air-based ADBEs has been studied in [78,79] to reduce energy losses of the envelope. Furthermore, either with or without mechanical ventilation, it is proposed to close the air cavity during certain occasions in order to avoid negative effects on occupants' thermal comfort caused by undesired ambient conditions [80]. Additionally, given the fact that the pre-heating of the air flowing in the cavity increases the efficiency of the air-based ADBE, geothermal energy systems are proposed to be integrated into the overall system $[81,82]$. 


\subsubsection{Solid-Based ADBE}

Solid-based ADBEs constitute a modern approach toward energy-efficient buildings as they can not only reduce the building's thermal losses but also reduce its electrical energy consumption. The main technology of this typology is the BIPV system $[83,84]$. This key element is the distinguishing factor of solid-based ADBEs compared to conventional façades [35]. More specifically, the BIPV is proposed to be placed on the outer surface of the façade, followed by an insulation layer, and (optionally) an air cavity between the aforementioned configuration and the existing wall, as presented in Figure 1. For the buildings located in the Northern Hemisphere, it is proposed to install the BIPV on the southern wall, whereas for the buildings located in the Southern Hemisphere, it is proposed to install BIPV on the north wall in order for the panels to produce maximum possible energy [85]. The panels can be either opaque or semi-transparent. The latter technology is also known as building-integrated semi-transparent photovoltaics (BISPVs), and it is beneficial to install it upon a window since it allows sunlight to enter the building through the respective glazing [86]. Furthermore, the excessive PV production can be stored in BESS with the utilization of the appropriate energy management system (EMS) [87].

The solid-based façades are often combined with BIPV/T, which produces heat through air-based systems [88]. The panels of the BIPV/T are generally semi-transparent and can be combined with many HVAC systems, PCMs, and other technologies [83,88,89]. This combination is highly promising as the building not only attains high rates of renewable electricity self-generation owing to the PV production but also substantially reduces its thermal loads because of the energy of the air flow inside the cavity, which can be further recovered through the respective systems.

\subsubsection{Kinetic ADBE}

The typology of kinetic ADBEs differs from the ones previously presented as it requires no working medium and is strongly dependent on control systems. More specifically, kinetic ADBEs may adjust the building's envelope through control systems so as to adjust the solar heat or light penetration to a desirable level, thus enhancing the thermal comfort and reducing the electricity consumption of the building. For this purpose, they may have a reconfigurable geometry or even rotate. In this vein, they may control the sunblinds and openings of the windows, as presented in [35]. The advanced possibilities of this typology include (amongst others) polarized film-systems covering the building's envelope, cellular automata, dynamic shading, and interactive designs that improve the daylight performance based on the occupant's position $[8,90]$. Furthermore, kinetic ADBEs may incorporate wind turbines (WTs) mounted on the façades of the building and generate electricity through wind energy, thus reducing the electricity consumption from the grid [91].

\subsubsection{Comparison of ADBE Typologies}

Summarizing, the ADBE typologies are water-based, air-based, solid-based, and kinetic [35]. We compared their key features in Table 2. Water-based and air-based ADBEs use more mature and simpler technologies than the rest of the typologies, which also results in their lower cost, while kinetic ADBEs require more advanced configurations and materials and have complex control systems [77,90,92]. Although all typologies enhance the thermal comfort of buildings, it should be noted that solid-based ADBEs also increase buildings' self-generation as they include PV panels. The building's self-generation may also be increased by kinetic ADBEs in the case where suitable WTs are part of the technical configuration. Solar radiation may enter the building through BISPV panels (which are part of the solid-based typology), water-glazing windows (which are part of the water-based typology), and specialized kinetic ADBEs. Finally, modern research focuses on solid-based ADBEs combined with air-based systems. The BIPVT systems produce electricity and at the same time utilize the heated air behind PV panels and the additional insulation layer to further improve the thermal comfort inside the building and reduce energy costs. 
Table 2. Comparison of ADBE typologies [35,77,90,92].

\begin{tabular}{ccccc}
\hline Cost & Water-Based & Air-Based & Solid-Based & Kinetic \\
\hline Popularity & Medium & Medium & High & High \\
\hline $\begin{array}{c}\text { Technology } \\
\text { maturity }\end{array}$ & Mature & Mature & In-progress & New technologies \\
\hline Control system & $\begin{array}{c}\text { Low } \\
\text { complexity }\end{array}$ & $\begin{array}{c}\text { Low } \\
\text { complexity }\end{array}$ & $\begin{array}{c}\text { Medium } \\
\text { complexity }\end{array}$ & Complex \\
\hline $\begin{array}{c}\text { Electricity } \\
\text { production }\end{array}$ & No & No & $\begin{array}{c}\text { Yes, through } \\
\text { PV panels }\end{array}$ & Yes, if WTs are incorporated \\
\hline $\begin{array}{c}\text { Main/usual } \\
\text { technologies }\end{array}$ & $\begin{array}{c}\text { Water pipes, } \\
\text { solar thermal } \\
\text { collectors }\end{array}$ & $\begin{array}{c}\text { Mechanical } \\
\text { ventilation }\end{array}$ & BIPV, PCM & $\begin{array}{c}\text { Adjustable envelopes } \\
\text { (sunblinds, film, and } \\
\text { advanced control system) }\end{array}$ \\
\hline
\end{tabular}

\section{Terminologies of ADBEs}

Throughout the literature, studies use different terminologies to point out the similar idea of an adaptive dynamic façade that responds to the changes of weather conditions. Adaptive facades enhance the energy efficiency properties of buildings through their resilient response to interior and exterior changing parameters, normally by implementing complex materials, technologies, and systems [93]. Loonen argues that the adaptive façades incorporate adaptive multifunctional technologies and materials, so that the entire envelope responds interactively to the changing indoor demand and outdoor ambient conditions in order to improve building performance [94]. Similarly, Davis uses the term climate adaptive building shell (CABS) to address the kind of envelope that interacts with different climate-related conditions [95,96]. The core concept of a Responsive Building Envelopes (RBEs) as extensions from CABS is that they mimic the responses of the building to climaterelated changes based on physiological responses found in nature [96,97]. RBEs exploit the potentials of combining active, passive, and controlling systems to replicate these natural phenomena in buildings and respond to indoor and outdoor triggers [98]. Some researchers consider the term 'adaptive solar façade' (ASF) to represent an adaptive façade improvised by solar system technologies that promotes better environmental performance of the building, which is often coupled by the possibility of controlling and using computers, apps, and gadgets $[99,100]$. Rossi et al. adopt this idea and introduce an 'adaptive solar envelope' (ASE) that couples a thin-film PV and mobile shades to exploit the sun radiation effectively and when desired [101]. The term 'smart façade' also refers to a similar notion of mixing passive and active systems with user controlling measures. Panopoulos and Papadopoulos describe the smart façade as an integrated hybrid system for dynamic control of solar radiation, shading, ventilation, and energy production, with high adaptability to climatic conditions and ability for regulation of solar radiation infiltration [102].

All the terms mentioned so far promote similar concepts and systems, with the keywords of multifunctional, adaptive, dynamic, and responsive, which overlap with one another. The concept of an ADBE lies in the domain of using active systems, passive systems, and a combination of both. However, with the wide variety of technologies being used, we identify two differentiating characteristics in order to be able to classify them for easier understanding. The first characteristic is the level of how active or passive the technologies used in the final ADBE product are. ADBE spans a wide variety of active building technologies, including technologies that exploit renewable energies such as PVs or solar air heaters, passive systems such as sunblinds, insulations, some types of storages, and PCM. Another differentiating factor among ADBE systems is the level of user controllability and occupant interaction with the façade, meaning if the user has the ability to operate some functions on the ADBE manually, or through the usage of building energy management systems (BEMS). Figure 2 shows the distribution of active and passive systems used in the ADBE research. The horizontal axis of the diagram ranges from passive 
to more active technologies and the vertical axis varies from completely fixed structures that the user cannot adjust to a totally adjustable system where the user can interact with the façade continuously. It appears that the passive systems are less interactive with the user, compared to more modern active technologies that benefit from BEMS. Additionally, it is clear that the more recent ADBEs developed are shifting towards the extensive usage of active technologies, mainly because of their energy harvesting potential, as well as the adaptiveness brought to the user through BEMS.

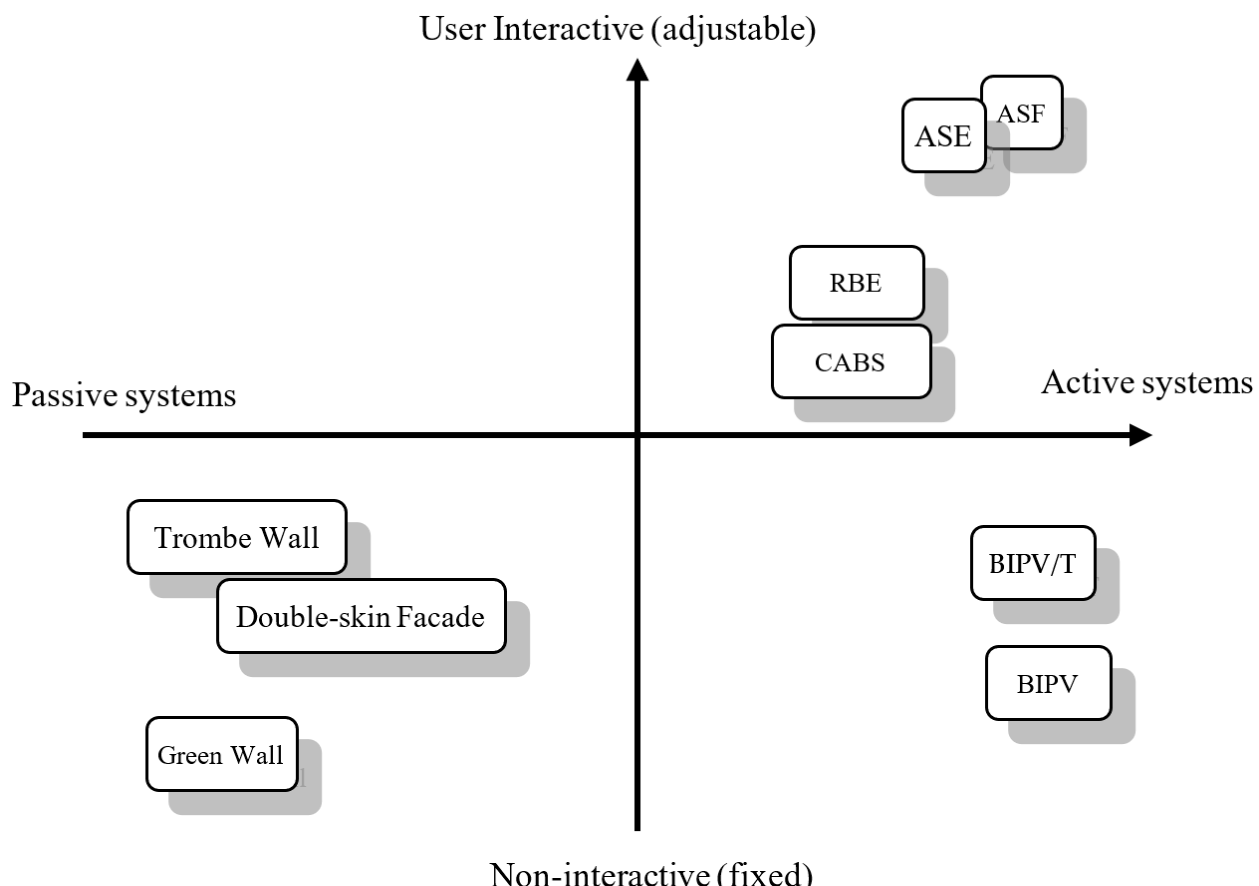

Figure 2. Distribution of ADBE systems using active and passive systems.

The efficiency of ADBEs varies widely because of the variety of systems coupled in them. Harish [29] states that HVAC systems contribute to an overall 20-60\% reduction in energy demand, 20-50\% in lighting demand, and 20-70\% in water heating and refrigeration demand. Some studies suggest even higher energy saving potential as high as $170 \%$ compared to a mass wall, when implementing a PV thermoelectric system [103]. Similarly, Luo integrates a PV thermoelectric module with a battery system in the envelope and shows that the proposed BIPV/T system achieved 72-92\% energy savings compared to a simple mass wall in a cold climate zone in China, while it increased to $88-100 \%$ in a mixed zone and topped $100 \%$ in a cooling dominant zone [104]. Hammad explored the energy consumption of an office building that devised their proposed external dynamic louvers and reported 34\%, 28\% and 30\% energy savings in southern, eastern and western facades [105]. Nagy et al. demonstrated and tested a novel ASF in order to balance the energy and emissions with the investment and operational costs in a prototype building and achieved a total energy saving of $25 \%$ compared to the fixed louver case with their proposed ASF [100]. Jayathissa et al. combine PV power generation with energy savings from adaptive PV shading and conclude that compared to an equivalent static PV shading system, approximately 20-80\% energy saving is expected, depending on the efficiency of the HVAC devices [106]. Kishore et al. provide a compelling demonstration of the advantages of utilizing PCM. They investigate a novel design that incorporates a PCM layer between two DIMS layers and find that this combined configuration performs better than if DIMS or PCM were used separately. Their findings show that the annual heat gain can be reduced by $15-72 \%$ and the annual heat loss can be reduced by $7-38 \%$ [24]. Bui et al. reach a $14.2-29 \%$ energy consumption reduction in the building using a computational optimization approach for designing an adaptive façade that adjusts to the changing 
ambient conditions by changing its thermal and light transmittance properties [107]. Hu and $\mathrm{Yu}$ address the fluctuating ambient conditions not through the walls but rather through a novel adaptive roof design that incorporates Thermo Chromic Phase Change Materials (TC/PCM) and reaches a $17 \%$ of total energy use reduction in the mild climate zones [23].

\section{Requirements of ADBE}

Various requirements must be considered in the design of ADBE. These requirements mainly comply with European EN standards and can be classified into the following categories:

- $\quad$ Energetic requirements;

- $\quad$ Static requirements;

- Safety requirements;

- Moisture protection requirements;

- Ecological requirements;

- $\quad$ Aesthetic requirements.

\subsection{Energetic Requirements}

Emissions caused due to building operation can be reduced either by reducing the final energy demand or by substituting fossil fuels with renewable energy sources (RES). Towards these objectives, ADBE can play a critical role through the improvement of the building's shell thermal properties and the harvesting of RES. As regards the first point, transmission losses influence the overall energy demand of a building. A German study suggests that improved qualities of glazing and exterior walls can result in up to 50\% less energy savings [108]. Especially in office buildings, a great portion of the façade often has very high U-value, which is three to four times more than a standard U-value for a new constructed building's minimum requirement. Great energy-saving potential can be inferred from this. Depending on the climate region that a country is located in, certain U-value requirements are developed to comply with its specific climate needs. For example, in Germany, the building energy act GEG [109] prescribes a maximum U-value of $0.24 \mathrm{~W} / \mathrm{m}^{2} / \mathrm{K}$ for outer walls of renovated buildings. In England, the UK building regulations [110] provide a maximum U-value of $0.30 \mathrm{~W} / \mathrm{m}^{2} / \mathrm{K}$ for the refurbishment of outer walls with internal or external wall insulation. ADBEs can lower the U-value of the outer wall by integrating insulation and increasing the thermal resistance of the wall.

Besides requirements regarding the U-values, additional restrictions on a building's primary energy demand and emission are made by each country. Those restrictions vary depending on the country. For example, in Germany, the building energy act GEG [109] defines a maximum value for the primary energy demand of a retrofitted building, in comparison with a reference building. To meet the requirements corresponding to the primary energy demand or emissions, the remaining energy demand can be covered by renewable energies. RES harvested on the façade can supply electricity or heat directly to the building and lower its primary energy demand. Section 3 therefore shows different technologies for energy harvesting in an ADBE as well as technologies for air conditioning, which can be operated with the generated renewable energy. Differences in the climate of each region influence the design of the ADBE. For example, in the Mediterranean climate, preventing overheating during long summer solar radiation may come be more important than heating. Therefore, sun protection in this region is of utmost importance. Furthermore, optimized ventilation, e.g., that is demand-led or with heat recovery, can reduce heat losses while maintaining or enhancing indoor thermal comfort.

\subsection{Static Requirements}

The possibility to assemble an additional façade with included technical components in front of the existing facade highly depends on the existing load-bearing structural system and how much extra weight it can bear. In Europe, the design bases are given by the series of Eurocodes [111]. Eurocode 0 [112] and 1 [113] specify the basic principles of structural 
design and the calculations of load effects. Eurocode 2-6 and 9 give the further calculation bases depending on the material used in the load-bearing structure of the ADBE. Special attention must be paid if an ADBE is used for retrofitting. In that case, the possibility to assemble an additional façade with included technical components in front of the existing one is directly related to the existing load-bearing structures and their remaining capacity.

Massive wall constructions are part of the primary load-bearing structure and can directly bear additional loads from the ADBE system. In contrast, skeleton structures transfer loads horizontally to the primary load-bearing structure, which might result in limitations for the structural implementation of ADBE elements. However, regardless of the design, it is necessary that potential fixing points of the load bearing structure are accessible. If the load-bearing capacity of a façade is sufficient, fixing to the ceiling construction could be a suitable solution for both skeleton and massive constructions. Furthermore, materialspecific aspects must be considered. The effect of temperature results in changes in length, which needs to be considered in the design and construction.

In addition to the load applied to the existing buildings, wind loads have to be calculated in the planning of ADBEs. Both the anchoring to the building and the fastening of the façade elements in the façade module must meet these requirements. The wind load is recorded by wind pressures and wind forces. Wind pressures can act both on external surfaces of structures (external pressure) and on internal surfaces (internal pressure) when the external envelope is permeable. The wind pressure acts perpendicular to the surface in question and is referred to as positive pressure in the case of compressive loading and negative pressure in the case of suction loading. In Europe, wind loads are considered according to Eurocode EN 1991-1-4 [113] and the respective national annexes.

Under seismic loading, the performance of the fasteners in a structure is crucial to its stability in order to avoid accidents and major economic impacts due to the collapse of non-structural elements. Seismic resistance of the façade elements and their connections and anchorages are to be determined in accordance with the national regulations of each country where the ADBE system is installed. In Europe, Eurocode 8 [114] regulates the requirements for earthquake safety.

\subsection{Safety Requirements}

Safety requirements mainly concern fire safety regulations. The requirements placed on a façade, from a fire protection point of view, depend on the type of construction and the type of building. The building regulations vary from country to country. According to the UK's building regulations schedule 1 B3 (1) [110] "the building shall be designed and constructed so that, in the event of fire, its stability will be maintained for a reasonable period". Other countries have comparable regulations. The Swedish Building Regulations [115] add the requirement that the risk of injuries to persons resulting from materials falling from the building façade must be limited. In Germany, the building regulation MBO § 28 [116] sets more detailed requirements to fire protections: in general, exterior walls and the elements devised in them should be designed in a way that the spread of fire on and in these components is sufficiently limited (MBO $\S 28(1)$ ). Non-load-bearing exterior walls and the elements and parts that are devised or attached to them, for example, technical components of an ADBE, shall consist of non-combustible building materials. If they are fire-retardant, they shall be permissible in flammable building materials (MBO § 28 (2)). Surfaces of external walls and coverings, including insulation materials and sub-structures, shall be of low flammability, but substructures of normally flammable mate-rials shall be permitted. In the planning of an ADBE, it must be checked if parts of the ADBE itself meet the requirements. The use of some technologies in ADBE, such as PCM or batteries, presents a challenge as they are flammable. For fire safety aspects of PCM, the work of Asimakopoulou et al. [117] describes the problems if the encapsulation of a PCM shells fail in case of fire. If technologies like PCM are used, it must be ensured that the ADBE maintains its stability for a reasonable period by protecting the technical components with layers of non-combustible building materials. Because of fire protection requirements, 
batteries are mostly not situated in the façade but inside the building. In some research, as in Luo et al. [104], implementation of batteries in the ADBE systems is discussed without referring to physical integration. Regarding BIPV, the work of Huang et al. [118] shows that there are possible designs to ensure the stability of PV systems for a reasonable period of time. Fire protection is an important point in the design of ADBE and should be part of any planning.

\subsection{Moisture Protection Requirements}

Moisture can affect a structure in either a liquid or gaseous state, affecting the longevity of a building and causing damage to the interior. Therefore, rainwater must be kept off by constructive measures that ensure drainage of the façade. Furthermore, care must be taken to ensure that all façade elements are rainproof and sealed. Particular attention must therefore be paid to the joint sealing. In addition to direct rainwater contamination, condensation of gaseous water can cause damage to a building. The sources of moisture can be manifold [119]: internal moisture sources such as those emitted by persons, the moisture content of outdoor air, and actively emitted moisture in evaporative cooled ADBEs with double skin facades, which are, for example, examined in the studies of Sotelo-Salas et al. [120] and Shen et al. [121] In such ADBEs, water is sprayed into the air cavity of a double skin façade and the evaporative effect is used to cool the building.

Water vapor can enter a building, if not directly emitted in the building, via the supply of air or diffuses through the building envelope. Condensation can form on the surface or inside of a building component if the temperature lays below the dew point temperature. This condensation leads to mould growth and results in health risks for users and residents. In addition, however, damage to the component or changes to its structural physics and structural functionality can also occur. Therefore, the occurrence of condensation on or in the building component should generally be avoided, or suitable measures should be taken or planned to prevent such consequences. On the one hand, this can be done by preventing the temperatures at the components' surfaces from falling below the dew point temperatures by installing an external insulation or increasing the room temperature. On the other hand, diffusion through the building components can be prevented by a vapordiffusion-tight construction method to avoid condensation inside the building envelope. Special attention on the vapor-diffusion-tightness must be paid in ADBEs with additional moisture emission as in evaporative cooled double skin facades. The building physics requirements for moisture protection vary from country to country. For example, DIN 4108-3 [115] defines requirements on climate-related moisture protection in Germany. Here, inter alia, requirements are formulated for the sealing of joints and façade surfaces for moisture protection. Comparable standards can be found in other countries, as for example the BS 5250 [122] in the UK.

\subsection{Ecological Requirements}

Regarding the ecological requirements, the entire life cycle of an ADBE is of interest. To ensure the best ecological performance, some prerequisites need to be met. Firstly, the overall use of raw materials should be minimized. Secondly, the production procedure is needed to present low energy demands and emissions. Thirdly, the whole system, or at least some parts of it, must be characterized by reusability or recyclability. During the definition of the ecological requirements, all phases of the life cycle of the ADBE should be considered: design, construction, use, repair and replacement, demolition, disposal, or (in the best-case scenario) deconstruction and reuse. In Europe, EN 15804 [116] establishes the basic rules for the sustainability of buildings.

\subsection{Aesthetic Requirements}

In addition to technical requirements, aesthetic concerns comprise a set of requirements regarding the appearance of ADBEs. Guidelines from local building authorities might define requirements to the aesthetic design of a building for certain districts. Despite those 
requirements, aesthetic ADBE design is not defined by sharp regulations and is in the eye of the beholder in each individual case. In general, the appearances of residential and non-residential buildings differ. Residential buildings tend to adapt the appearance of the surroundings with subdued and natural colours and low reflections. Non-residential building façades tend to implement a design with more modern elements, such as glazing; aluminium; or partially exposed technologies, such as PV-cells.

\section{Literature Analysis}

In order to find the most prevalent trends in technology selection and other designrelated criteria in the ADBEs, we conducted a systematic literature search to find the most frequently occurring trends. We found 117 articles and conference papers altogether that had developed a dynamic façade that adapted to environmental conditions or gave an overview over façade systems [12,14,19-26,28,33-36,38,41-43,45,53,65-69,78,83,84,88,98, $100,103-106,123-189]$. The time scale covered in our study is from 2006 to 2020 . We analyzed the studies based on their scale, building construction type, climate and geographical distribution, and prevalent active and passive technologies.

\subsection{Scale}

Considering the scale of the ADBE research, it is evident that the majority of papers focus on solutions for single buildings (91\%) (Figure 3a) and usually do not investigate the effect of their ADBE on an urban district. This includes the development of dynamic envelopes and BIPV modules, which are widely studied. An example for such a case study can be found in Kim et al. [141], where the authors conducted a simulation study on air-type BIPVT systems. In this study, the electrical and thermal performance of an air type BIPV/T system was evaluated in comparison to a BIPV system. As it was previously mentioned, only a small portion of publications focus on urban scale. More specifically, only $2 \%$ of the papers consider an urban scale. In this context, the work of Radweik et al. [42] investigated the solar energy potential of buildings, including the differentiation between the potential on roofs and façades. Another example is the work of Saretta et al. [176], who developed a 3D method based on a geographical information system (GIS) for assessing BIPV retrofit potential of façades in an urban scale. The studies that did not evaluate the implementation of their system, were mainly in an early stage of development, were marked as "Not Specified", and accounted for 7\% of the studies. In this case, many of the projects developed a first prototype of the façade system, like Gallo et al. [21] who focused on the design, testing, and construction of a smart façade system. Another example of the category "Not Specified" can be found in the work of Gaur et al. [156], where mathematical models for BISPV/T systems were developed and experimentally verified.

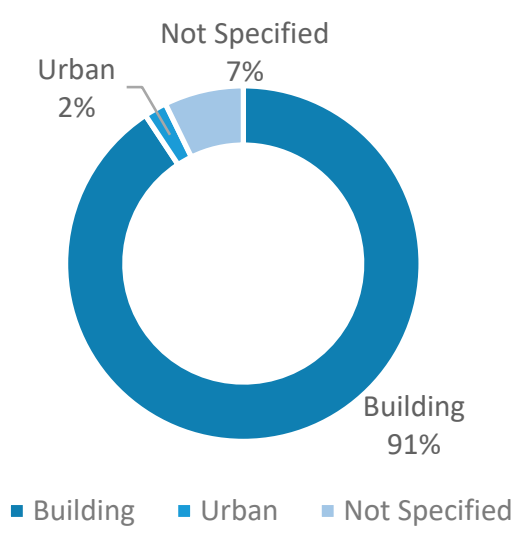

(a)

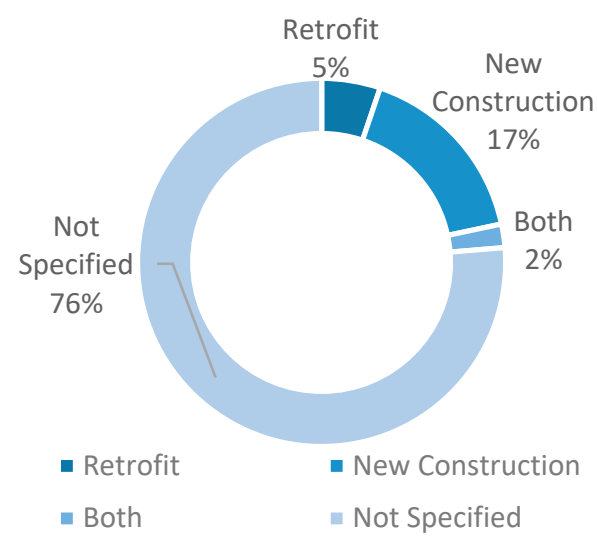

(b)

Figure 3. Scale (a) and building construction type (b) of 117 ADBE publications between 2006 and 2020. 
Most of the research considers ADBEs without specifying if they could be used in new buildings or in retrofit (see Figure $3 b$ ). This can be justified by the high number of papers that carry out theoretical considerations or develop prototypes. For instance, Khire et al. [136] present a methodology for optimal design of adaptive systems without specifying their scale. Li et al. [137] studied the energetic and economic aspects of semitransparent PVs as a single building component. In this case, it is not specified if the PV panel could be used in new construction or retrofit, and it is therefore counted in the category "Not Specified" since the installation of solutions for retrofit requires different details that should be provided by designers.

In most cases, where the use case of the ADBE has been specified, the system is developed for new construction. Perez et al. [124] present the life cycle impacts of a BIPV array that was implemented on a new constructed test building in New York. It is evident from the observations that only a few studies explicitly address the requirements of retrofit. For example, Sorgato et al. [166] demonstrate that replacing traditional façade building elements such as architectural glass with PV modules can result in economic benefits. Another example is given by Stazi et al. [142], who found in their case study that a ventilated coating was the most suitable option in their renovation case. Their system consists of external insulation separated from the internal wall by an air channel. It can be operated in two configurations to ventilate the air channel, mainly during summer, and close it during winter. This provides good insulation in winter and prevents overheating in summer. The work of Ciardiello et al. [170] presents an approach for the design optimization of an ADBE for both existing and new buildings. Given the importance of renovating existing buildings to meet climate neutrality goals in the building sector, the need for further research and the development of ADBE solutions that are suitable as part of the retrofit actions need to be identified.

Most of the papers are reluctant to specify the construction type of building that the ADBE solution is developed for. Two-thirds of the papers in our study focus more on the development of an ADBE system rather than its realization on a building level and do not provide information about the building construction type. These are categorized under "Not specified" in Figure 4. In this figure, 27\% of the studies provide an application in office buildings. Examples can be found in the work of Miranda et al. [181] and Kim et al. [141]. Miranda et al. [181] consider the implementation of origami sunscreens to the façade of an office building to harvest mechanical energy. Kim et al. [141] evaluate the electrical and thermal performance of air type BIPVT systems by simulating a two-story office building. The consideration of residential buildings is comparatively rare, but there is research regarding this purpose as well. For example, Chen at al. [53] show the implementation of a BIPV system in existing houses in a cold climate. Considering that the occupancy rate differs significantly between office and residential buildings, it appears that the studies should base their considerations on case studies that use more representative occupancy specifications and boundary conditions.

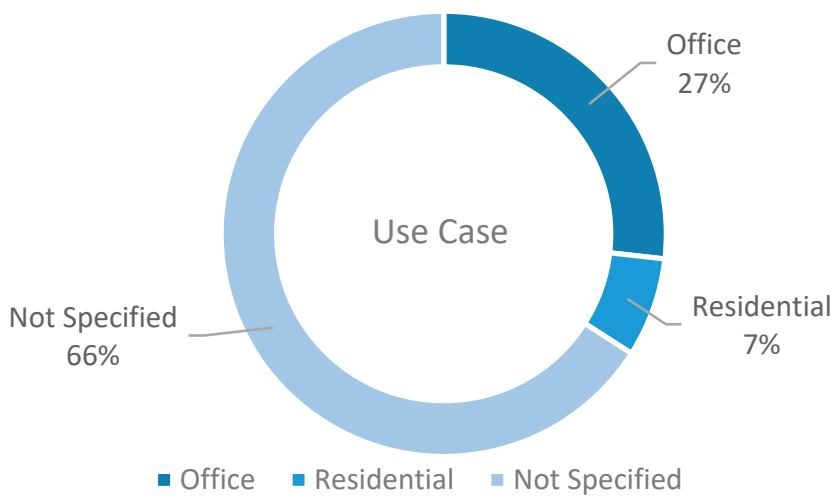

Figure 4. Building usage types of the ADBE systems. 


\subsection{Method of Study}

To evaluate the used methods of the studies, we clustered the papers into the following categories: experimental, simulation, review, and other. The results are shown in Figure 5. Several papers conduct both simulation studies and experiments. Therefore, Figure $5 \mathrm{a}$ shows also a graph for simulation and experiment whereby these papers are also included in the categories simulation or experiment. Papers in the category "Other" use methods that cannot be included in the rest of the groups. For example, Garrain et al. [175] evaluated socioeconomic or environmental aspects of façade BIPV systems by analyzing their life cycle emissions and economic benefits. Another example for the category can be found in the work of Saretta et al. [176]. The work assessed BIPV retrofit potentials based on a 3D method using geographical information.

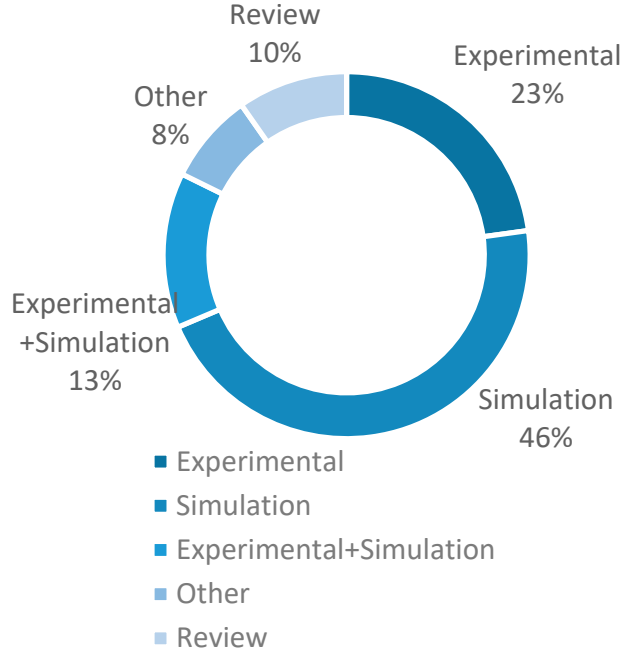

(a)

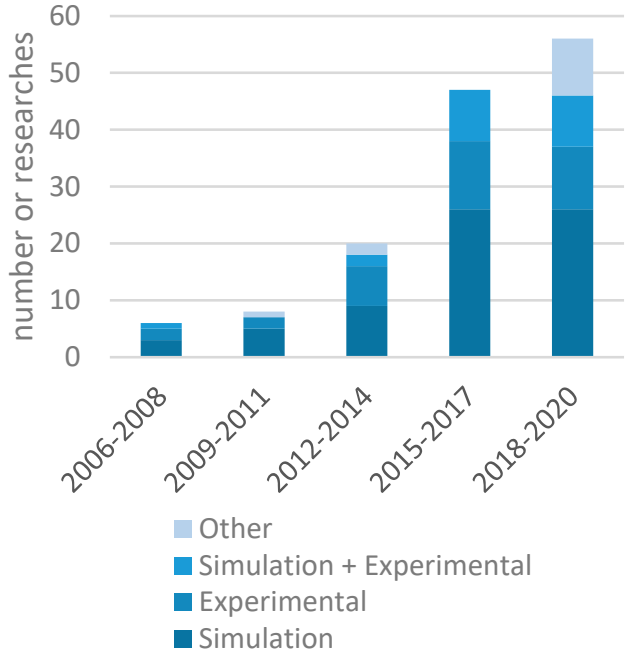

(b)

Figure 5. Share of used methods in ADBE research (a) and trend of used methods in research over the years 2006-2020 (b).

A share of almost $46 \%$ of the papers conducted research using simulation methodologies. In most of these papers, dynamic software tools were used to predict the energy consumption of a building. Tools used in these studies were, for example, EnergyPlus $[23,25,107]$ and TRNSYS $[19,128,151,155]$. These studies concluded their results, based on the simulations that showed the impact of their ADBE systems. Other researchers used numerical calculations to evaluate the potential of their ADBE systems. Hailu et al. [151] presented a mathematical model for calculation of insolation of a BIPV thermal system when tested in the shadow condition.

In $23 \%$ of the studies, experimental methods were conducted. As there is another category "Experimental + Simulation" in Figure 5a, the research listed here does not contain simulations. In most cases, researchers developed and tested technologies of ADBE systems either in-field or in laboratories. For example, Mei et al. [138] tested a PV tiled roof under laboratory conditions, and Li et al. [137] evaluated BISPV systems in a case building. It is the case that $13 \%$ of the publications adopted both numerical and experimental methodologies. Most of them considered BIPV or BIPVT systems and compared the simulated and measured performance. These studies showed good agreements between simulation and experiment. Luo et al. [104] determined, in a field test, an averaged absolute simulation error for the surface temperature to be $0.61{ }^{\circ} \mathrm{C}$ and the PV output of a BIPVT system of $0.1 \mathrm{~A}$ on a summer day. In winter day conditions, these values were reported to be $0.61{ }^{\circ} \mathrm{C}$ and $0.22 \mathrm{~A}$. Bellazzi et al. [165] gave a standard deviation of the percentage difference from simulated and experimentally tested BIPV modules between $2 \%$ and $7 \%$ for different types of days. Goncalves et al. [167] identified, in a sensitivity analysis, the 
convective heat transfer coefficient as the parameter with the strongest influence on the performance of BIPVT simulation models. Experimental validations for technologies other than BIPV are more likely to be found. Zhang et al. [79] tested an exhaust air insulation wall under unsteady-state boundary conditions in a test cell and received good agreement with their models. In this framework, Han et al. [145] investigated the performance of a ventilated double-sided PV façade.

In this study, we also considered 17 review papers, constituting a share of $10 \%$ of the publications. Only a few of them used the terminology of ADBE (see Section 3) but all of them addressed topics about integrating adaptive components in the building envelope. However, in the following sections regarding the technologies and distribution of the studies, we only considered research papers as they contributed to a mature, innovative system, and left out the conference papers. Mentions in review papers that conducted a meta-analysis of different research papers are also excluded with the same idea. Thus, we concentrated on the development of ADBE systems in the research field. Figure 5b shows the increasing amount of research papers over the years, addressing the topic of ADBEs. It is clear that the studies that used simulation as a methodology account for most of the overall increase in the number of papers, next to studies that used other innovative methods. In the period from 2018-2020,61\% of the research used simulations, of which $16 \%$ also conducted experiments, and $19 \%$ of the research carried out experiments to validate their project idea. The ratio of the different methods remains almost constant over the years.

\subsection{Climatical and Geographical Distribution}

Regarding the climate-related distribution, most of the papers investigate ADBE systems in temperate climate zones, such as in the middle and north of Europe. The second most frequent climate zone refers to the subtropical zone, e.g., southern Europe. Investigations in cooling dominant tropical zones are not numerous but are also found in the literature, whereas only six research studies focus on ADBE systems in polar and subpolar zones.

Figure 6 illustrates the distribution of the publications by geographic domain based on the real location or the conditions supposed during the conduction of the studies. Many of the research studies consider boundary conditions of China. There is also a large amount of research in south European climate conditions such as Spain, where increased usage of PV panels is crucial for energy harvesting due to high solar radiation in those countries.

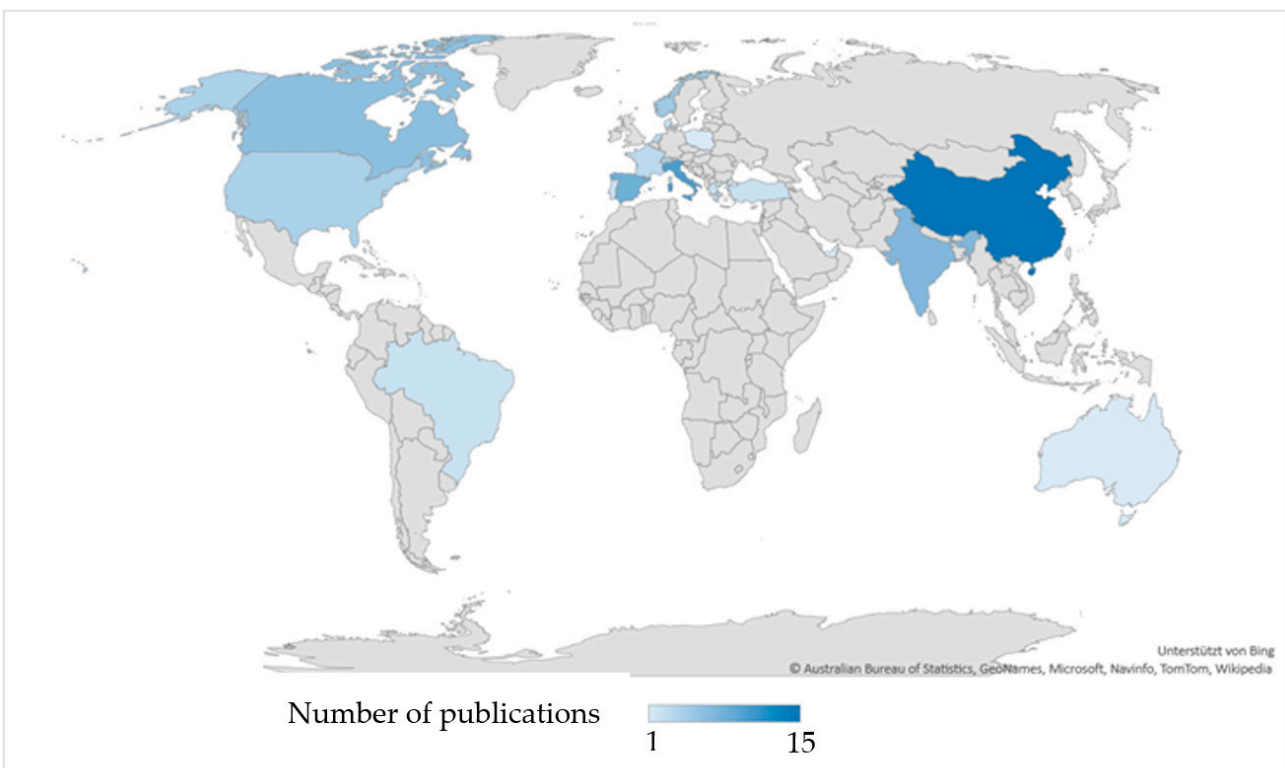

Figure 6. Geographical distribution of publications. 
The evaluation shows that most of the research studies consider temperate and subtropical climate zones. This is probably because most research is carried out in more developed countries, which consider the climate conditions of their own country. Additionally, BIPV, which is one of the most attractive technologies used in ADBEs, can work most efficiently in locations with high radiation, as in southern Europe.

\subsection{Prevalent Technologies}

Table 1 summarizes 13 general technologies that can be included in an ADBE system. These technologies refer to a range of active and passive solutions that differ significantly between each other in terms of cost, maturity, applicability, efficiency, popularity, etc. The investigated studies usually couple a number of these general technologies that we introduced in Section 2 and produce more creative and specific solutions. To assess the technology that each study had used, we selected the more dominant technology that they had combined with one another. The BIPV and BIPV/T, which are two of the most representative systems of the active technologies, are both included under the 'PV' category for an easier classification of studies that exploit benefits of solar energy. The same idea was applied in the case of 'PCM storage', 'BESS', and 'sensible heat storage' since all were summarized under the category 'storage'. Finally, wind turbine technologies were excluded from the analysis of active technologies due to extremely limited application.

\subsubsection{Active Technologies}

Considering the active technologies implemented in the ADBEs, it is noticeable that PV panels are the most utilized technology in the research papers (Figure 7a). BIPV, $\mathrm{BIPV} / \mathrm{T}$, and PVs are included in over 60 studies. This is mainly attributed to their inherent energy production characteristics, which are hardly replaceable by any other technology. The second most used technology is mechanical ventilation (MV), which is included in 20 studies. Thirteen studies consider the implementation of heat pumps in the façade, whereas nine studies integrate thermoelectric elements. In addition, solar air heaters are only used in two papers $[26,45]$. Technologies that occur only once in the projects listed in Figure 7a are included under the category "Other". In this specific group, the work of Lyu et al. [68] investigated water flow windows.

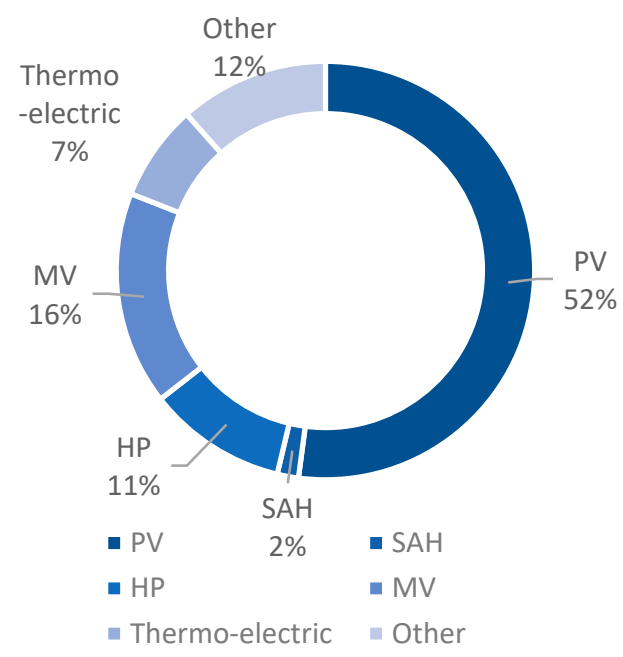

(a)

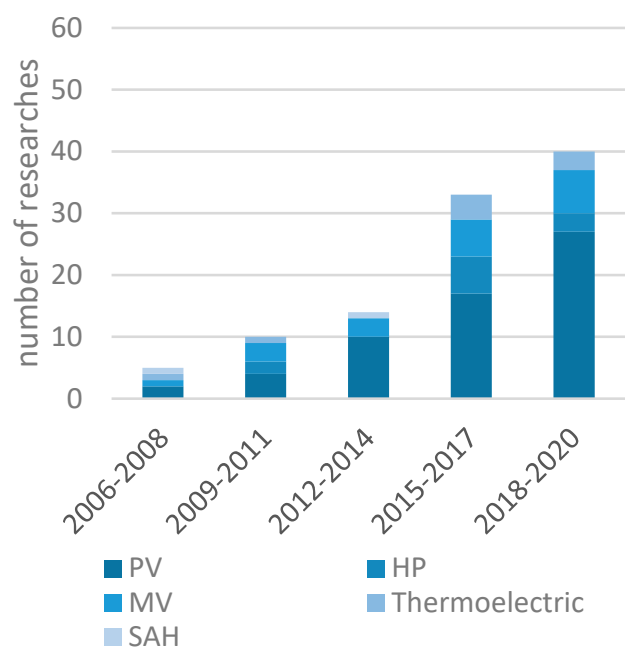

(b)

Figure 7. Active technologies included in the research papers (a); trend of using different active technologies over the years 2006-2020 (b).

Figure $7 \mathrm{~b}$ shows the trend of the usage of active technologies in ADBE systems during the period 2006-2020. As in Section 5.2, it can be seen again that the overall number of 
studies developing ADBEs is raising over time. Yet, the increasing number of studies including PV elements in recent years has been striking. More specifically, the percentage of research considering PV in ADBE has grown from 40\% in the 2006-2008 period to 68\% in the 2018-2020 period. It can further be observed that mechanical ventilation was used sparingly in the research papers over the entire period. Since 2016, a slight increase in the number of papers considering mechanical ventilation has occurred. Thermoelectric elements were of greater research interest in the years 2006-2008 than in recent years. From 2006-2008, they made up 20\% of the research. After that, thermoelectric elements were less frequently addressed in the research. Since then, only in the years 2017 and 2018, an increased number of papers with thermoelectrical elements have been published. In summary, most research on ADBE technology concerns the integration of PV elements.

\subsubsection{Passive Technologies and Storages}

Passive technologies for ADBE systems are considered in over half of the investigated studies. Figure 8 a shows the share of passive technologies used in the papers. A standalone ADBE can hardly perform without the contribution of passive envelope technologies [35]. Insulation is mentioned in many of the studies as it is the key basic element to reduce heat losses. However, we only labelled ADBE studies under insulation category that intensively focus their research interest on insulation. As a result, the number of studies using insulation in Figure 8a seems relatively low compared to the frequent spread of insulation in façade systems. In this context, the work of Lopez et al. [41] considered the insulation as a part of a multifunctional BIPV system that contributes significantly to the heat loss control.

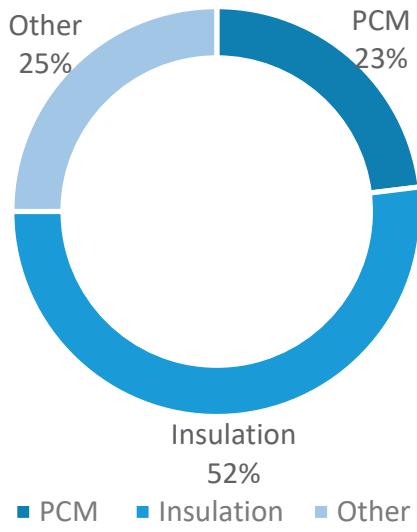

(a)

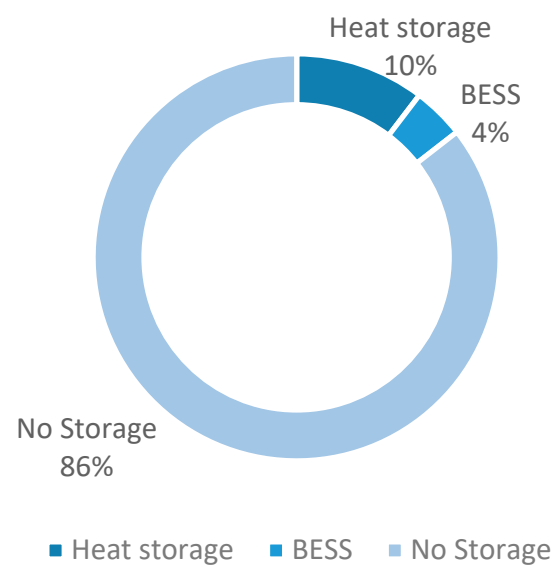

(b)

Figure 8. Percentage of studies using passive technologies (a) and share of used storages (b).

The implementation of PCM in the building façade is observed in $23 \%$ of the publications considering passive technologies. Zhang et al. [150] carried out simulations to estimate the adaptability of PCM on building envelopes. Favoino et al. [26] integrated PCM actively as a heat storage in their multifunctional façade. Other heat storages are rarely implemented in ADBEs because of their high weight. Nevertheless, some ADBEs actively use other heat storages that are not integrated in the building's envelope, as a part of a building energy system. The usage of water tanks for heat storage is the most common approach. Delisle et al. [158] use a water tank to store either the heat of a BIPV/T system or a heat pump powered by a PV-panel. Tardif et al. [128] investigate another possibility of heat storage. In their research, an ice-slurry latent storage tank is coupled with a water source heat pump as part of a heat management strategy of an air-based $\mathrm{BIPV} / \mathrm{T}$ system. A variety of different technologies are combined in the category "other" in 
Figure 8a. Those account for technologies such as biocomposite materials in façades [171] or the implementation of an innovative-coupled glass with an internal IR treatment [66].

In addition to heat storages, in some works battery storages are considered. As Figure $8 \mathrm{~b}$ shows, those are inferior in number to the usage of heat storages. An example for the implementation of batteries can be found in the work of Luo et al. [104], where up to $100 \%$ energy savings are indicated by using BIPV/T in combination with a battery storage.

\section{Discussion and Roadmap}

Paving the way from traditional to ADBE façade is not only demanding on the design process but also challenging in simulations, field-testing, and exploitation business plans. This is mainly due to the fact that the mere addition of adaptive systems to the façade does not guarantee successful operation [96]. In this endeavor, certain obstacles are foreseen that must be tackled by researchers and decision makers. Figure 9 illustrates these barriers of ADBE realization through the statistical analysis of this paper.

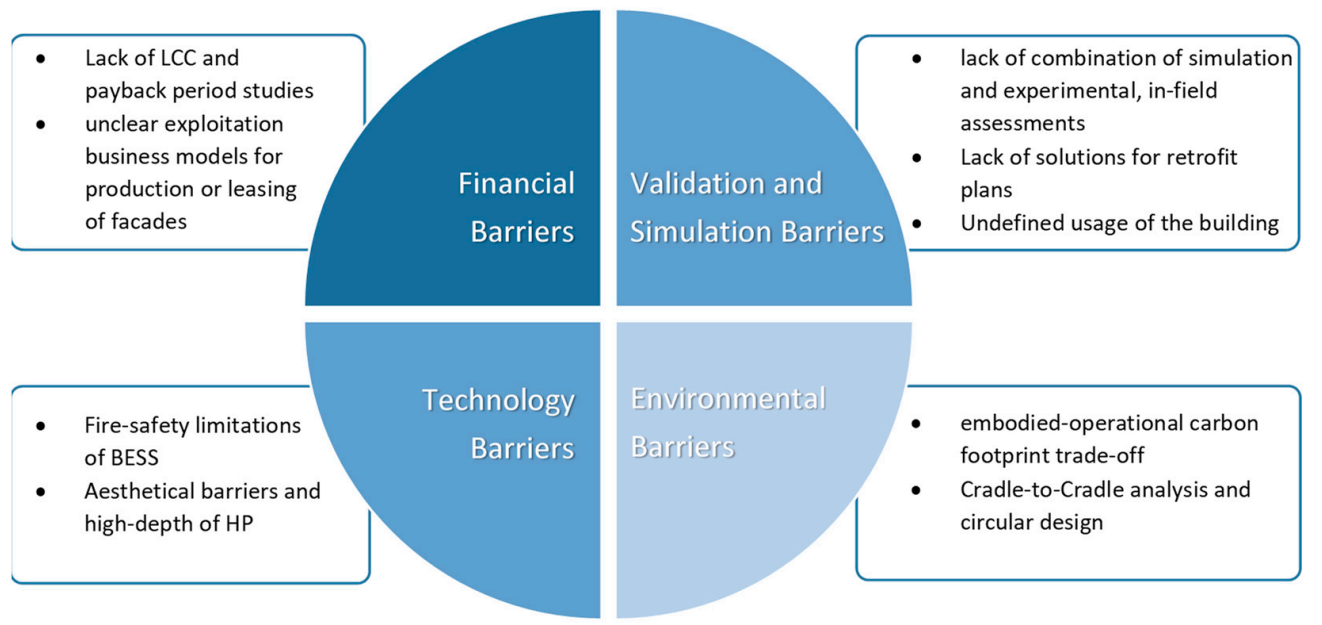

Figure 9. Barriers of ADBE successful implementation.

The ADBE projects often involve innovative technologies, resulting in simulationbased studies that are not necessarily combined with field-testing. This is found through methodology investigation of studies that show $46 \%$ of research methods use simulation method alone, and only $13 \%$ of them couple simulations with experimental work. It is clearly visible in the studies that most of them do not provide experimental testing and develop prototypes for a pilot building. It is sometimes the case that a specific mix of technologies is investigated in a theoretical design but not accompanied with detailed energy modeling or experimental investigations [80]. This seems to be a key specific issue that needs to be attended to in future research by focusing on more combination of simulation and experimental work that involves field-testing.

Developing an ADBE for an existing building's façade as a retrofit action is what seems to be missing in the literature. Most studies have not mentioned whether the developed design or prototype is dedicated to a new construction or usable for a retrofit project, and only $5 \%$ of the studies specifically target retrofit solutions. Retrofit design requires developing attachment and dismantling details for installation, which affects the design procedure of the final product. This is crucial, especially when considering the difference of installing the ADBE as a standalone solution for replacement of the existing façade or as an attachment to the old façade. Nonetheless, the literature does not show many research efforts oriented in this direction.

The majority of studies conducted so far have also neglected building usage and merely developed an energy efficient façade that does not necessarily correspond to residential, office, or other usages of the building, even though the occupancy schedules 
differ significantly, which affects the efficiency of a designed ADBE. For example, an ADBE system with SAH technology might not necessarily contribute to an office's thermal comfort because it produces heat during daytime, where there are high internal gains due to the high number of employees and their electronic devices such as computers.

Technologies used in the ADBE façades show significant usage of PVs compared to other active technologies. More than half of the studies exploit the energy production capabilities of PVs either as a BIPV, BIPV/T, or a solo element. This clearly reflects the potential of a power-generating technology as the base technology for ADBE design. Heat pumps are only addressed in $11 \%$ of ADBE studies, even though they have become very popular in past years. This is mainly due to the fact that it is hard to implement a completely integrated heat pump in the façade due to its high weight, thickness, and the scarcity of low-depth solutions, all resulting in a thick façade, which is not favorable aesthetically. Implementing battery-based systems seems to also have limitations, considering their flammability risk.

Project owners are often precautious to adopt advanced façades because of the higher risks of payback period due to higher initial investment and, often, maintenance costs. In the literature investigation, we seldom encountered payback analysis of the developed ADBEs, which also ranged vastly from 5.2 years [19] to 22 years [179], certainly not enough to draw a conclusion for the investors. Therefore, it would be beneficial if the ADBE designers included payback period analysis when designing the façade. The same lack of studies was also seen in life cycle analysis (LCA), life cycle costs (LCC), and circular business plans. Since the materials devised in an ADBE are often complex and have an initial high embedded carbon, it is very crucial to conduct LCA of the final ADBE product. The LCA studies conducted on a specific ADBE are very limited [190,191] but suggest promising environmental offset due to considerable reduction of energy demand. Developing circular business plans such as leasing façades for retrofit may have the potential to increase trust and security for owners to adopt such solutions in their retrofit program.

\section{Conclusions}

In this review paper, the general aspects of ADBE designs are discussed to classify and discover the latest trends in terms of technology selection among different ADBE systems. This review contributes to the better classification of passive and active ADBE systems and enriches the knowledge of the type and the frequency of each technology and the way in which it is used in the whole design. The most attractive technology is PVs since they are easy to implement on the façade surface and are the most prevalent technology in the energy generation market. Although heat pumps have been raising popularity in building HVAC systems in the past years, they are still not as attractive in the façade design as they are for the whole building design.

Developing an ADBE for an existing building's façade as a retrofit action is found to be unattended in the literature, which needs to be addressed due to different installation requirements. It was also found that most studies conducted so far have neglected building usage and merely developed an energy-efficient façade without taking occupants into consideration, which leads to unrealistic high efficiency of design. The scarcity in experimental studies was another significant gap that should be addressed by future studies through combining simulations with in-field testings. Moreover, it was highlighted that the exploitation plans for mass-production of these innovative ADBEs are still far from realization, and clear business models are required.

Author Contributions: Conceptualization, N.M.; methodology, N.M., N.F.; writing-original draft preparation, N.M., N.F., M.F. and P.D.; writing-review and editing, N.M., N.F., M.F., P.D. and R.S.; project administration, T.O.; funding acquisition, D.M. All authors have read and agreed to the published version of the manuscript.

Funding: This study is funded by the European Union Horizon 2020 research and innovation program under project "Plug-n-Harvest" with grant agreement No. 768735. 


\section{Institutional Review Board Statement: Not applicable.}

Conflicts of Interest: The authors declare no conflict of interest.

\section{References}

1. Buildings and Climate Change: Status, Challenges, and Opportunities-Pekka Huovila-Google Books. Available online: https:/ / books.google.de/books?hl=en\&lr=\&id=-lgab8igWgcC\&oi=fnd\&pg=PA30\&dq=Buildings+and+climate+change+ unep\&ots=E-_icjHfh_\&sig=QuieteezuD7Zu8iuJtNtiGTkj_Y\&redir_esc=y (accessed on 6 November 2021).

2. Du, H.; Huang, P.; Jones, P. Modular facade retrofit with renewable energy technologies: The definition and current status in Europe. Energy Build. 2019, 205, 109543. [CrossRef]

3. Kalisz, D.E.; Aluchna, M. Research and innovations redefined. Perspectives on european union initiatives and strategic choices on horizon 2020. Eur. Integr. Stud. 2012, 6, 140-149. [CrossRef]

4. COST Action TU1403-Adaptive Facades Network-Webpage of COST Action TU1403. Available online: http://tu1403.eu/ (accessed on 6 January 2022).

5. IEA SHC. Task 56 | | Publications. Available online: https://task56.iea-shc.org/publications (accessed on 6 January 2022).

6. IEA SHC. Task 60 | | Publications. Available online: https://task60.iea-shc.org/publications (accessed on 6 January 2022).

7. Building Envelope Design with the Objective to Ensure Thermal, Visual and Acoustic Comfort Conditions-ScienceDirect. Available online: https://www.sciencedirect.com/science/article/abs/pii/S0360132303001410?via\%3Dihub (accessed on 6 November 2021).

8. Hosseini, S.M.; Mohammadi, M.; Schröder, T.; Guerra-Santin, O. Integrating interactive kinetic façade design with colored glass to improve daylight performance based on occupants' position. J. Build. Eng. 2020, 31, 101404. [CrossRef]

9. Towards Sustainable-Energy Buildings—Sciencedirect. Available online: https://www.sciencedirect.com/science/article/abs/ pii/S030626190300059X?via\%3Dihub (accessed on 5 November 2021).

10. Reinterpreting Sustainable Architecture: The Place of Technology on JSTOR. Available online: https://www.jstor.org/stable/14 25580 (accessed on 5 November 2021).

11. Elgizawy, E.M. The Effect of Green Facades in Landscape Ecology. Procedia Environ. Sci. 2016, 34, 119-130. [CrossRef]

12. Talaei, M.; Mahdavinejad, M.; Zarkesh, A.; Motevali Haghighi, H. A Review on Interaction of Innovative Building Envelope Technologies and Solar Energy Gain. Energy Procedia 2017, 141, 24-28. [CrossRef]

13. Zhou, J.; Chen, Y. A review on applying ventilated double-skin facade to buildings in hot-summer and cold-winter zone in China. Renew. Sustain. Energy Rev. 2010, 14, 1321-1328. [CrossRef]

14. Zhang, T.; Tan, Y.; Yang, H.; Zhang, X. The application of air layers in building envelopes: A review. Appl. Energy 2016, 165, 707-734. [CrossRef]

15. Hu, Z.; He, W.; Ji, J.; Zhang, S. A review on the application of Trombe wall system in buildings. Renew. Sustain. Energy Rev. 2017, 70, 976-987. [CrossRef]

16. Yedder, R.B.; Bilgen, E. Natural convection and conduction in Trombe wall systems. Int. J. Heat Mass Transf. 1991, 34, 1237-1248. [CrossRef]

17. Akeiber, H.; Nejat, P.; Majid, M.Z.A.; Wahid, M.A.; Jomehzadeh, F.; Zeynali Famileh, I.; Calautit, J.K.; Hughes, B.R.; Zaki, S.A. A review on phase change material (PCM) for sustainable passive cooling in building envelopes. Renew. Sustain. Energy Rev. 2016, 60, 1470-1497. [CrossRef]

18. Phase Change Material Based Thermal Storage for Energy Conservation in Building Architecture. Available online: https: //www.researchgate.net/publication/228823294_Phase_Change_Material_based_thermal_storage_for_energy_conservation_ in_building_architecture (accessed on 5 November 2021).

19. Calise, F.; Cappiello, F.L.; Dentice d'Accadia, M.; Vicidomini, M. Dynamic modelling and thermoeconomic analysis of micro wind turbines and building integrated photovoltaic panels. Renew. Energy 2020, 160, 633-652. [CrossRef]

20. de Gracia, A. Dynamic building envelope with PCM for cooling purposes-Proof of concept. Appl. Energy 2019, 235, 1245-1253. [CrossRef]

21. Gallo, P.; Romano, R. Adaptive Facades, Developed with Innovative Nanomaterials, for a Sustainable Architecture in the Mediterranean Area. Procedia Eng. 2017, 180, 1274-1283. [CrossRef]

22. Bigaila, E.; Athienitis, A.K. Modeling and simulation of a photovoltaic/thermal air collector assisting a façade integrated small scale heat pump with radiant PCM panel. Energy Build. 2017, 149, 298-309. [CrossRef]

23. $\mathrm{Hu}, \mathrm{J} . ; \mathrm{Yu}, \mathrm{X}$. Thermo and light-responsive building envelope: Energy analysis under different climate conditions. Sol. Energy 2019, 193, 866-877. [CrossRef]

24. Kishore, R.A.; Bianchi, M.V.A.; Booten, C.; Vidal, J.; Jackson, R. Enhancing building energy performance by effectively using phase change material and dynamic insulation in walls. Appl. Energy 2021, 283, 116306. [CrossRef]

25. Hu, J.; Yu, X. (Bill) Adaptive building roof by coupling thermochromic material and phase change material: Energy performance under different climate conditions. Constr. Build. Mater. 2020, 262, 120481. [CrossRef]

26. Favoino, F.; Goia, F.; Perino, M.; Serra, V. Experimental assessment of the energy performance of an advanced responsive multifunctional façade module. Energy Build. 2014, 68, 647-659. [CrossRef] 
27. Wachenfeldt, B.J.; Bell, D. Building Integrated Energy Systems in Smart Energy Efficient Buildings-A State-of-the Art. 35. Available online: https://www.sintef.no/globalassets/upload/building-integrated-energy-systems-in-smart-energy-efficientbuildings-a-state-of-the-art.pdf (accessed on 6 January 2022).

28. Kant, K.; Pitchumani, R.; Shukla, A.; Sharma, A. Analysis and design of air ventilated building integrated photovoltaic (BIPV) system incorporating phase change materials. Energy Convers. Manag. 2019, 196, 149-164. [CrossRef]

29. Harish, V.S.K.V.; Kumar, A. A review on modeling and simulation of building energy systems. Renew. Sustain. Energy Rev. 2016, 56, 1272-1292. [CrossRef]

30. Hosseini, S.M.; Mohammadi, M.; Rosemann, A.; Schröder, T.; Lichtenberg, J. A morphological approach for kinetic façade design process to improve visual and thermal comfort: Review. Build. Environ. 2019, 153, 186-204. [CrossRef]

31. Tabadkani, A.; Roetzel, A.; Li, H.X.; Tsangrassoulis, A. Design approaches and typologies of adaptive facades: A review. Autom. Constr. 2021, 121, 103450. [CrossRef]

32. Tabadkani, A.; Roetzel, A.; Li, H.X.; Tsangrassoulis, A. A review of occupant-centric control strategies for adaptive facades. Autom. Constr. 2021, 122, 103464. [CrossRef]

33. Bedon, C.; Honfi, D.; Machalická, K.V.; Eliášová, M.; Vokáč, M.; Kozłowski, M.; Wüest, T.; Santos, F.; Portal, N.W. Structural characterisation of adaptive facades in Europe-Part I: Insight on classification rules, performance metrics and design methods. $J$. Build. Eng. 2019, 25, 100721. [CrossRef]

34. Juaristi, M.; Gómez-Acebo, T.; Monge-Barrio, A. Qualitative analysis of promising materials and technologies for the design and evaluation of Climate Adaptive Opaque Façades. Build. Environ. 2018, 144, 482-501. [CrossRef]

35. Luo, Y.; Zhang, L.; Bozlar, M.; Liu, Z.; Guo, H.; Meggers, F. Active building envelope systems toward renewable and sustainable energy. Renew. Sustain. Energy Rev. 2019, 104, 470-491. [CrossRef]

36. Shahin, H.S.M. Adaptive building envelopes of multistory buildings as an example of high performance building skins. Alex. Eng. J. 2019, 58, 345-352. [CrossRef]

37. van Roosmalen, M.; Herrmann, A.; Kumar, A. A review of prefabricated self-sufficient facades with integrated decentralised HVAC and renewable energy generation and storage. Energy Build. 2021, 248, 111107. [CrossRef]

38. Kumar Nigam, P.; Akhtar, S. Retrofitting practices in various categories of RCC structures-A comprehensive review. Mater. Today Proc. 2021, 45, 7123-7131. [CrossRef]

39. Kourtzanidis, K.; Angelakoglou, K.; Apostolopoulos, V.; Giourka, P.; Nikolopoulos, N. Assessing Impact, Performance and Sustainability Potential of Smart City Projects: Towards a Case Agnostic Evaluation Framework. Sustainability 2021, $13,7395$. [CrossRef]

40. Freitas, S.; Brito, M.C. Solar façades for future cities. Renew. Energy Focus 2019, 31, 73-79. [CrossRef]

41. López, C.S.P.; Frontini, F.; Friesen, G.; Friesen, T. Experimental Testing under Real Conditions of Different Solar Building Skins when Using Multifunctional BIPV Systems. Energy Procedia 2014, 48, 1412-1418. [CrossRef]

42. Redweik, P.; Catita, C.; Brito, M. Solar energy potential on roofs and facades in an urban landscape. Sol. Energy 2013, 97, 332-341. [CrossRef]

43. Roeleveld, D.; Hailu, G.; Fung, A.S.; Naylor, D.; Yang, T.; Athienitis, A.K. Validation of Computational Fluid Dynamics (CFD) Model of a Building Integrated Photovoltaic/Thermal (BIPV/T) System. Energy Procedia 2015, 78, 1901-1906. [CrossRef]

44. Georgiou, L.; Souliotis, M.; Papaefthimiou, S.; Fokaides, P.A. Numerical simulation data of building integrated solar thermal collectors under diverse conditions. Data Brief 2021, 39, 107470. [CrossRef] [PubMed]

45. Mei, L.; Infield, D.; Eicker, U.; Loveday, D.; Fux, V. Cooling potential of ventilated PV façade and solar air heaters combined with a desiccant cooling machine. Renew. Energy 2006, 31, 1265-1278. [CrossRef]

46. Rezaeiha, A.; Montazeri, H.; Blocken, B. A framework for preliminary large-scale urban wind energy potential assessment: Roof-mounted wind turbines. Energy Convers. Manag. 2020, 214, 112770. [CrossRef]

47. de Gracia, A.; Navarro, L.; Castell, A.; Ruiz-Pardo, Á.; Alvárez, S.; Cabeza, L.F. Experimental study of a ventilated facade with PCM during winter period. Energy Build. 2013, 58, 324-332. [CrossRef]

48. Mukhamet, T.; Kobeyev, S.; Nadeem, A.; Memon, S.A. Ranking PCMs for building façade applications using multi-criteria decision-making tools combined with energy simulations. Energy 2021, 215, 119102. [CrossRef]

49. Yu, G.; Yang, H.; Luo, D.; Cheng, X.; Ansah, M.K. A review on developments and researches of building integrated photovoltaic (BIPV) windows and shading blinds. Renew. Sustain. Energy Rev. 2021, 149, 111355. [CrossRef]

50. Alessandro, M.; Aste, N.; Claudio, D.P.; Fabrizio, L. Photovoltaic-thermal solar-assisted heat pump systems for building applications: Integration and design methods. Energy Built Environ. 2021, S2666123321000507. [CrossRef]

51. Yang, L.W.; Xu, R.J.; Hua, N.; Xia, Y.; Zhou, W.B.; Yang, T.; Belyayev, Y.; Wang, H.S. Review of the advances in solar-assisted air source heat pumps for the domestic sector. Energy Convers. Manag. 2021, 247, 114710. [CrossRef]

52. Pekdogan, T.; Tokuç, A.; Ezan, M.A.; Başaran, T. Experimental investigation on heat transfer and air flow behavior of latent heat storage unit in a facade integrated ventilation system. J. Energy Storage 2021, 44, 103367. [CrossRef]

53. Chen, Y.; Athienitis, A.K.; Galal, K. Modeling, design and thermal performance of a BIPV/T system thermally coupled with a ventilated concrete slab in a low energy solar house: Part 1, BIPV/T system and house energy concept. Sol. Energy 2010, 84, 1892-1907. [CrossRef]

54. Wang, P.; Liu, Z.; Chen, D.; Li, W.; Zhang, L. Experimental study and multi-objective optimisation of a novel integral thermoelectric wall. Energy Build. 2021, 252, 111403. [CrossRef] 
55. Heier, J.; Bales, C.; Martin, V. Combining thermal energy storage with buildings-A review. Renew. Sustain. Energy Rev. 2015, 42, 1305-1325. [CrossRef]

56. Castro, M.T.; Del Rosario, J.A.D.; Chong, M.N.; Chuang, P.-Y.A.; Lee, J.; Ocon, J.D. Multiphysics modeling of lithium-ion, lead-acid, and vanadium redox flow batteries. J. Energy Storage 2021, 42, 102982. [CrossRef]

57. Campana, P.E.; Cioccolanti, L.; François, B.; Jurasz, J.; Zhang, Y.; Varini, M.; Stridh, B.; Yan, J. Li-ion batteries for peak shaving, price arbitrage, and photovoltaic self-consumption in commercial buildings: A Monte Carlo Analysis. Energy Convers. Manag. 2021, 234, 113889. [CrossRef]

58. Navarro, L.; de Gracia, A.; Colclough, S.; Browne, M.; McCormack, S.J.; Griffiths, P.; Cabeza, L.F. Thermal energy storage in building integrated thermal systems: A review. Part 1. active storage systems. Renew. Energy 2016, 88, 526-547. [CrossRef]

59. Sarbu, I.; Sebarchievici, C. A Comprehensive Review of Thermal Energy Storage. Sustainability 2018, 10, 191. [CrossRef]

60. Čurpek, J.; Čekon, M. Climate response of a BiPV façade system enhanced with latent PCM-based thermal energy storage. Renew. Energy 2020, 152, 368-384. [CrossRef]

61. Curado, A.; de Freitas, V.P. Influence of thermal insulation of facades on the performance of retrofitted social housing buildings in Southern European countries. Sustain. Cities Soc. 2019, 48, 101534. [CrossRef]

62. Yüksel, A.; Arıcı, M.; Krajčík, M.; Civan, M.; Karabay, H. A review on thermal comfort, indoor air quality and energy consumption in temples. J. Build. Eng. 2021, 35, 102013. [CrossRef]

63. Zou, B.; Peng, J.; Li, S.; Li, Y.; Yan, J.; Yang, H. Comparative study of the dynamic programming-based and rule-based operation strategies for grid-connected PV-battery systems of office buildings. Appl. Energy 2022, 305, 117875. [CrossRef]

64. Heinz, A.; Rieberer, R. Energetic and economic analysis of a PV-assisted air-to-water heat pump system for renovated residential buildings with high-temperature heat emission system. Appl. Energy 2021, 293, 116953. [CrossRef]

65. Alkhatib, H.; Lemarchand, P.; Norton, B.; O'Sullivan, D.T.J. Deployment and control of adaptive building facades for energy generation, thermal insulation, ventilation and daylighting: A review. Appl. Therm. Eng. 2021, 185, 116331. [CrossRef]

66. Pugsley, A.; Zacharopoulos, A.; Deb Mondol, J.; Smyth, M. BIPV/T facades-A new opportunity for integrated collector-storage solar water heaters? Part 1: State-of-the-art, theory and potential. Sol. Energy 2020, 207, 317-335. [CrossRef]

67. Brottier, L.; Naudin, S.; Veeser, V.; Terrom, G.; Bennacer, R. Field Test Results of an Innovative PV/T Collector for Solar Domestic Hot Water. Energy Procedia 2016, 91, 276-283. [CrossRef]

68. Lyu, Y.; Wu, X.; Li, C.; Su, H.; He, L. Numerical analysis on the effectiveness of warm water supply in water flow window for room heating. Sol. Energy 2019, 177, 347-354. [CrossRef]

69. Martin-Escudero, K.; Salazar-Herran, E.; Campos-Celador, A.; Diarce-Belloso, G.; Gomez-Arriaran, I. Solar energy system for heating and domestic hot water supply by means of a heat pump coupled to a photovoltaic ventilated façade. Sol. Energy $\mathbf{2 0 1 9}$ 183, 453-462. [CrossRef]

70. Liu, C.; Lyu, Y.; Li, C.; Li, J.; Zhuo, K.; Su, H. Thermal performance testing of triple-glazing water flow window in cooing operation. Sol. Energy 2021, 218, 108-116. [CrossRef]

71. D'Antoni, M.; Saro, O. Energy potential of a Massive Solar-Thermal Collector design in European climates. Sol. Energy 2013, 93, 195-208. [CrossRef]

72. Zhu, Q.; Li, A.; Xie, J.; Li, W.; Xu, X. Experimental validation of a semi-dynamic simplified model of active pipe-embedded building envelope. Int. J. Therm. Sci. 2016, 108, 70-80. [CrossRef]

73. Zhu, Q.; Xu, X.; Wang, J.; Xiao, F. Development of dynamic simplified thermal models of active pipe-embedded building envelopes using genetic algorithm. Int. J. Therm. Sci. 2014, 76, 258-272. [CrossRef]

74. Alaidroos, A.; Krarti, M. Optimized controls for ventilated wall cavities with spray evaporative cooling systems. Energy Build. 2017, 154, 356-372. [CrossRef]

75. Huang, M.; Hao, X.; Li, C. Heat and Mass Transfer of Evaporative Wall and Its Cooling Load Calculation. Procedia Eng. 2017, 205, 2762-2770. [CrossRef]

76. Alaidroos, A.; Krarti, M. Numerical modeling of ventilated wall cavities with spray evaporative cooling system. Energy Build. 2016, 130, 350-365. [CrossRef]

77. Chen, Y.; Tong, Z.; Zheng, Y.; Samuelson, H.; Norford, L. Transfer learning with deep neural networks for model predictive control of HVAC and natural ventilation in smart buildings. J. Clean. Prod. 2020, 254, 119866. [CrossRef]

78. Pflug, T.; Kuhn, T.E.; Nörenberg, R.; Glück, A.; Nestle, N.; Maurer, C. Closed translucent façade elements with switchable U -value-A novel option for energy management via the facade. Energy Build. 2015, 86, 66-73. [CrossRef]

79. Zhang, C.; Wang, J.; Li, L.; Gang, W. Dynamic thermal performance and parametric analysis of a heat recovery building envelope based on air-permeable porous materials. Energy 2019, 189, 116361. [CrossRef]

80. Ibáñez-Puy, M.; Martín-Gómez, C.; Vidaurre-Arbizu, M.; Sacristán-Fernández, J.A. Theoretical Design of an Active Façade System with Peltier Cells. Energy Procedia 2014, 61, 700-703. [CrossRef]

81. Elghamry, R.; Hassan, H. Impact a combination of geothermal and solar energy systems on building ventilation, heating and output power: Experimental study. Renew. Energy 2020, 152, 1403-1413. [CrossRef]

82. Zeiler, W.; Boxem, G. Geothermal Active Building Concept. In Sustainability in Energy and Buildings; Howlett, R.J., Jain, L.C., Lee, S.H., Eds.; Springer: Berlin/Heidelberg, Germany, 2009; pp. 305-314. [CrossRef]

83. Biyik, E.; Araz, M.; Hepbasli, A.; Shahrestani, M.; Yao, R.; Shao, L.; Essah, E.; Oliveira, A.C.; del Caño, T.; Rico, E.; et al. A key review of building integrated photovoltaic (BIPV) systems. Eng. Sci. Technol. Int. J. 2017, 20, 833-858. [CrossRef] 
84. de Freitas, J.S.; Cronemberger, J.; Soares, R.M.; Amorim, C.N.D. Modeling and assessing BIPV envelopes using parametric Rhinoceros plugins Grasshopper and Ladybug. Renew. Energy 2020, 160, 1468-1479. [CrossRef]

85. Atmaja, T.D. Façade and Rooftop PV Installation Strategy for Building Integrated Photo Voltaic Application. Energy Procedia 2013, 32, 105-114. [CrossRef]

86. Shukla, A.K.; Sudhakar, K.; Baredar, P. Exergetic analysis of building integrated semitransparent photovoltaic module in clear sky condition at Bhopal India. Case Stud. Therm. Eng. 2016, 8, 142-151. [CrossRef]

87. Fotopoulou, M.C.; Drosatos, P.; Petridis, S.; Rakopoulos, D.; Stergiopoulos, F.; Nikolopoulos, N. Model Predictive Control for the Energy Management in a District of Buildings Equipped with Building Integrated Photovoltaic Systems and Batteries. Energies 2021, 21, 3369. [CrossRef]

88. Debbarma, M.; Sudhakar, K.; Baredar, P. Comparison of BIPV and BIPVT: A review. Resour. Effic. Technol. 2017, 3, 263-271. [CrossRef]

89. Zisopoulos, G.; Nesiadis, A.; Atsonios, K.; Nikolopoulos, N.; Stitou, D.; Coca-Ortegón, A. Conceptual design and dynamic simulation of an integrated solar driven thermal system with thermochemical energy storage for heating and cooling. J. Energy Storage 2021, 41, 102870. [CrossRef]

90. Zawidzki, M. Dynamic shading of a building envelope based on rotating polarized film system controlled by one-dimensional cellular automata in regular tessellations (triangular, square and hexagonal). Adv. Eng. Inform. 2015, 29, 87-100. [CrossRef]

91. Filipowicz, M.; Goryl, W.; Żołądek, M. Study of building integrated wind turbines operation on the example of Center of Energy AGH. IOP Conf. Ser. Earth Environ. Sci. 2019, 214, 012122. [CrossRef]

92. Fletcher, T.H. Integrated Gasification Combined Cycle (IGCC) Technologies; Wang, T., Ed.; Woodhead Publishing Series in Energy; Woodhead, Elsevier: Amsterdam, The Netherlands, 2017.

93. Aelenei, D.; Aelenei, L.; Vieira, C.P. Adaptive Façade: Concept, Applications, Research Questions. Energy Procedia 2016, 91, 269-275. [CrossRef]

94. Loonen, R.; Rico-Martinez, J.M.; Favoino, F.; Brzezicki, M.; Ménézo, C.; La Ferla, G.; Aelenei, L. Design for façade adaptabilityTowards a unified and systematic characterization. In Proceedings of the 10th Energy Forum-Advanced Building Skins, Bern, Switzerland, 3-4 November 2015; pp. 1274-1284.

95. Addington, M. Contingent Behaviours. Archit. Des. 2009, 79, 12-17. [CrossRef]

96. Loonen, R.C.G.M.; Trčka, M.; Cóstola, D.; Hensen, J.L.M. Climate adaptive building shells: State-of-the-art and future challenges. Renew. Sustain. Energy Rev. 2013, 25, 483-493. [CrossRef]

97. Loonen, R. Bio-Inspired Adaptive Building Skins. Biotechnol. Biomim. Civ. Eng. 2015, 115-134. Available online: https: / /link.springer.com/chapter/10.1007/978-3-319-09287-4_5\#citeas (accessed on 10 November 2021).

98. Taveres-Cachat, E.; Grynning, S.; Thomsen, J.; Selkowitz, S. Responsive building envelope concepts in zero emission neighborhoods and smart cities-A roadmap to implementation. Build. Environ. 2019, 149, 446-457. [CrossRef]

99. Meagher, M. Designing for change: The poetic potential of responsive architecture. Front. Archit. Res. 2015, 4, 159-165. [CrossRef]

100. Nagy, Z.; Svetozarevic, B.; Jayathissa, P.; Begle, M.; Hofer, J.; Lydon, G.; Willmann, A.; Schlueter, A. The Adaptive Solar Facade: From concept to prototypes. Front. Archit. Res. 2016, 5, 143-156. [CrossRef]

101. Rossi, D.; Nagy, Z.; Schlueter, A. Adaptive Distributed Robotics for Environmental Performance, Occupant Comfort and Architectural Expression. Int. J. Archit. Comput. 2012, 10, 341-359. [CrossRef]

102. Panopoulos, K.; Papadopoulos, A.M. Smart facades for non-residential buildings: An assessment. Adv. Build. Energy Res. 2017, 11, 26-36. [CrossRef]

103. Luo, Y.; Zhang, L.; Liu, Z.; Wu, J.; Zhang, Y.; Wu, Z.; He, X. Performance analysis of a self-adaptive building integrated photovoltaic thermoelectric wall system in hot summer and cold winter zone of China. Energy 2017, 140, 584-600. [CrossRef]

104. Luo, Y.; Zhang, L.; Liu, Z.; Yu, J.; Xu, X.; Su, X. Towards net zero energy building: The application potential and adaptability of photovoltaic-thermoelectric-battery wall system. Appl. Energy 2020, 258, 114066. [CrossRef]

105. Hammad, F.; Abu-Hijleh, B. The energy savings potential of using dynamic external louvers in an office building. Energy Build. 2010, 42, 1888-1895. [CrossRef]

106. Jayathissa, P.; Zarb, J.; Luzzatto, M.; Hofer, J.; Schlueter, A. Sensitivity of Building Properties and Use Types for the Application of Adaptive Photovoltaic Shading Systems. Energy Procedia 2017, 122, 139-144. [CrossRef]

107. Bui, D.-K.; Nguyen, T.N.; Ghazlan, A.; Ngo, N.-T.; Ngo, T.D. Enhancing building energy efficiency by adaptive façade: A computational optimization approach. Appl. Energy 2020, 265, 114797. [CrossRef]

108. Deutsche Energie-Agentur GmbH (dena) Dena-Studie: Auswertung von Verbrauchskennwerten energieeffizienter Wohngebäude 2016. Available online: https:/ / www.dena.de/fileadmin/dena/Dokumente/Pdf/9164_dena-Studie._Auswertung_von_ Verbrauchskennwerten_energieeffizienter_Wohngebaeude.pdf (accessed on 10 November 2021).

109. Bundesministerium der Justiz. Gesetz zur Einsparung von Energie und zur Nutzung Erneuerbarer Energien zur Wärme- und Kälteerzeugung in Gebäuden. 2020. Available online: https:/ / www.gesetze-im-internet.de/geg/ (accessed on 10 November 2021).

110. The Building Regulations. 2010. Available online: https://www.legislation.gov.uk/uksi/2010/2214/contents/made (accessed on 10 November 2021).

111. European Commitee For Standartization EN Eurocode. Available online: https://eurocodes.jrc.ec.europa.eu/showpage.php?id= 13 (accessed on 10 November 2021). 
112. European Commitee For Standartization. Eurocode-Basis of Structural Design; European Commitee For Standartization: Brussels, Belgium, 2005.

113. European Commitee For Standartization. Eurocode 1: Actions on Structures; European Commitee For Standartization: Brussels, Belgium, 2002.

114. European Commitee For Standartization. Eurocode 8: Design of Structures for Earthquake Resistance; European Commitee For Standartization: Brussels, Belgium, 2004.

115. Deutsches Institut für Normung e.V. Thermal Protection and Energy Economy in Buildings—Part 3: Protection Against Moisture Subject to Climate Conditions-Requirements, Calculation Methods and Directions for Planning and Construction. 2018. Available online: https:/ / standards.globalspec.com/std/13083128/din-4108-3 (accessed on 21 January 2022).

116. European Commitee For Standartization. Sustainability of Construction Works-Environmental Product Declarations-Core Rules for the Product Category of Construction Products, B S I Standards, 1912; European Commitee For Standartization: Brussels, Belgium, 2012.

117. Asimakopoulou, E.K.; Kolaitis, D.I.; Founti, M.A. Fire safety aspects of PCM-enhanced gypsum plasterboards: An experimental and numerical investigation. Fire Saf. J. 2015, 72, 50-58. [CrossRef]

118. Huang, D.; Li, Q.; Yuan, X. Comparison between hot-gas bypass defrosting and reverse-cycle defrosting methods on an air-towater heat pump. Appl. Energy 2009, 86, 1697-1703. [CrossRef]

119. Brambilla, A.; Sangiorgio, A. Moisture and Buildings: Durability Issues, Health Implications and Strategies to Mitigate the Risks, 1st ed.; Brambilla, A., Ed.; Elsevier: Waltham, MA, USA, 2021.

120. Sotelo-Salas, C.; Pozo, C.E.; Esparza-López, C.J. Thermal assessment of spray evaporative cooling in opaque double skin facade for cooling load reduction in hot arid climate. J. Build. Eng. 2021, 38, 102156. [CrossRef]

121. Shen, C.; Li, X. Thermal performance of double skin façade with built-in pipes utilizing evaporative cooling water in cooling season. Sol. Energy 2016, 137, 55-65. [CrossRef]

122. Sanders, C.; Consulting, G. Management of Moisture in Buildings-CODE of Practice. Available online: https: / / www.bsigroup com/en-GB/blog/Built-Environment-Blog/bs-5250-2021-management-of-moisture-in-buildings--code-of-practice/ (accessed on 6 January 2022).

123. Zhang, X.; Lovati, M.; Vigna, I.; Widén, J.; Han, M.; Gal, C.; Feng, T. A review of urban energy systems at building cluster level incorporating renewable-energy-source (RES) envelope solutions. Appl. Energy 2018, 230, 1034-1056. [CrossRef]

124. Perez, M.J.R.; Fthenakis, V.; Kim, H.-C.; Pereira, A.O. Façade-integrated photovoltaics: A life cycle and performance assessment case study: Façade-integrated PV, life cycle, performance assessment. Prog. Photovolt. Res. Appl. 2012, 20, 975-990. [CrossRef]

125. Deo, A.; Mishra, G.K.; Tiwari, G.N. A thermal periodic theory and experimental validation of building integrated semi-transparent photovoltaic thermal (BiSPVT) system. Sol. Energy 2017, 155, 1021-1032. [CrossRef]

126. Mishra, G.K.; Tiwari, G.N. Performance evaluation of $7.2 \mathrm{kWp}$ standalone building integrated semi-transparent photovoltaic thermal system. Renew. Energy 2020, 146, 205-222. [CrossRef]

127. Arkar, C.; Žižak, T.; Domjan, S.; Medved, S. Dynamic parametric models for the holistic evaluation of semi-transparent photovoltaic/thermal façade with latent storage inserts. Appl. Energy 2020, 280, 115994. [CrossRef]

128. Tardif, J.M.; Tamasauskas, J.; Delisle, V.; Kegel, M. Performance of Air Based BIPV/T Heat Management Strategies in a Canadian Home. Procedia Environ. Sci. 2017, 38, 140-147. [CrossRef]

129. Yang, S.; Cannavale, A.; Di Carlo, A.; Prasad, D.; Sproul, A.; Fiorito, F. Performance assessment of BIPV/T double-skin façade for various climate zones in Australia: Effects on energy consumption. Sol. Energy 2020, 199, 377-399. [CrossRef]

130. Barozzi, M.; Lienhard, J.; Zanelli, A.; Monticelli, C. The Sustainability of Adaptive Envelopes: Developments of Kinetic Architecture. Procedia Eng. 2016, 155, 275-284. [CrossRef]

131. Prieto, A.; Knaack, U.; Auer, T.; Klein, T. COOLFACADE: State-of-the-art review and evaluation of solar cooling technologies on their potential for façade integration. Renew. Sustain. Energy Rev. 2019, 101, 395-414. [CrossRef]

132. Zuazua-Ros, A.; Martín-Gómez, C.; Ibañez-Puy, E.; Vidaurre-Arbizu, M.; Gelbstein, Y. Investigation of the thermoelectric potential for heating, cooling and ventilation in buildings: Characterization options and applications. Renew. Energy 2019, 131, 229-239. [CrossRef]

133. Irshad, K.; Habib, K.; Saidur, R.; Kareem, M.W.; Saha, B.B. Study of thermoelectric and photovoltaic facade system for energy efficient building development: A review. J. Clean. Prod. 2019, 209, 1376-1395. [CrossRef]

134. Li, Q.; Zanelli, A. A review on fabrication and applications of textile envelope integrated flexible photovoltaic systems. Renew. Sustain. Energy Rev. 2021, 139, 110678. [CrossRef]

135. O'Grady, T.; Chong, H.-Y.; Morrison, G.M. A systematic review and meta-analysis of building automation systems. Build. Environ. 2021, 195, 107770. [CrossRef]

136. Khire, R.A.; Messac, A. Selection-Integrated Optimization (SIO) Methodology for Optimal Design of Adaptive Systems. J. Mech Des. 2008, 130, 101401. [CrossRef]

137. Li, D.H.W.; Lam, T.N.T.; Chan, W.W.H.; Mak, A.H.L. Energy and cost analysis of semi-transparent photovoltaic in office buildings. Appl. Energy 2009, 86, 722-729. [CrossRef]

138. Mei, L.; Infield, D.G.; Gottschalg, R.; Loveday, D.L.; Davies, D.; Berry, M. Equilibrium thermal characteristics of a building integrated photovoltaic tiled roof. Sol. Energy 2009, 83, 1893-1901. [CrossRef]

139. Hoes, P.; Hensen, J.L.M.; Loomans, M.G.L.C.; de Vries, B.; Bourgeois, D. User behavior in whole building simulation. Energy Build. 2009, 41, 295-302. [CrossRef] 
140. Nielsen, M.V.; Svendsen, S.; Jensen, L.B. Quantifying the potential of automated dynamic solar shading in office buildings through integrated simulations of energy and daylight. Sol. Energy 2011, 85, 757-768. [CrossRef]

141. Kim, J.-H.; Kim, J.-T. A Simulation Study of Air-Type Building-Integrated Photovoltaic-Thermal System. Energy Procedia 2012, 30, 1016-1024. [CrossRef]

142. Stazi, F.; Vegliò, A.; Di Perna, C.; Munafò, P. Retrofitting using a dynamic envelope to ensure thermal comfort, energy savings and low environmental impact in Mediterranean climates. Energy Build. 2012, 54, 350-362. [CrossRef]

143. Lee, E.S.; Claybaugh, E.S.; LaFrance, M. End user impacts of automated electrochromic windows in a pilot retrofit application. Energy Build. 2012, 47, 267-284. [CrossRef]

144. Peng, J.; Lu, L.; Yang, H.; Han, J. Investigation on the annual thermal performance of a photovoltaic wall mounted on a multi-layer façade. Appl. Energy 2013, 112, 646-656. [CrossRef]

145. Han, J.; Lu, L.; Peng, J.; Yang, H. Performance of ventilated double-sided PV façade compared with conventional clear glass façade. Energy Build. 2013, 56, 204-209. [CrossRef]

146. Kamel, R.S.; Fung, A.S. Modeling, simulation and feasibility analysis of residential BIPV/T+ASHP system in cold climateCanada. Energy Build. 2014, 82, 758-770. [CrossRef]

147. Bakker, L.G.; Hoes-van Oeffelen, E.C.M.; Loonen, R.C.G.M.; Hensen, J.L.M. User satisfaction and interaction with automated dynamic facades: A pilot study. Build. Environ. 2014, 78, 44-52. [CrossRef]

148. Favoino, F.; Jin, Q.; Overend, M. Towards an Ideal Adaptive Glazed Façade for Office Buildings. Energy Procedia 2014, 62, 289-298. [CrossRef]

149. Goia, F.; Cascone, Y. The Impact of an Ideal Dynamic Building Envelope on the Energy Performance of Low Energy Office Buildings. Energy Procedia 2014, 58, 185-192. [CrossRef]

150. Zhang, H.; Sun, X.; Zhang, Q.; Liao, S.; He, Y. Estimating the Adaptability of Phase Change Material Board on Building Envelope of Telecommunications Base Stations. Procedia Eng. 2015, 121, 1665-1673. [CrossRef]

151. Hailu, G.; Dash, P.; Fung, A.S. Performance Evaluation of an Air Source Heat Pump Coupled with a Building-Integrated Photovoltaic/Thermal (BIPV/T) System under Cold Climatic Conditions. Energy Procedia 2015, 78, 1913-1918. [CrossRef]

152. Rounis, E.D.; Bigaila, E.; Luk, P.; Athienitis, A.; Stathopoulos, T. Multiple-inlet BIPV/T Modeling: Wind Effects and Fan Induced Suction. Energy Procedia 2015, 78, 1950-1955. [CrossRef]

153. Favoino, F.; Overend, M.; Jin, Q. The optimal thermo-optical properties and energy saving potential of adaptive glazing technologies. Appl. Energy 2015, 156, 1-15. [CrossRef]

154. Lee, E.S.; Gehbauer, C.; Coffey, B.E.; McNeil, A.; Stadler, M.; Marnay, C. Integrated control of dynamic facades and distributed energy resources for energy cost minimization in commercial buildings. Sol. Energy 2015, 122, 1384-1397. [CrossRef]

155. Saadon, S.; Gaillard, L.; Giroux-Julien, S.; Ménézo, C. Simulation study of a naturally-ventilated building integrated photovoltaic/thermal (BIPV/T) envelope. Renew. Energy 2016, 87, 517-531. [CrossRef]

156. Gaur, A.; Tiwari, G.N.; Ménézo, C.; Al-Helal, I.M. Numerical and experimental studies on a Building integrated Semi-transparent Photovoltaic Thermal (BiSPVT) system: Model validation with a prototype test setup. Energy Convers. Manag. 2016, 129, 329-343. [CrossRef]

157. Skandalos, N.; Karamanis, D. Investigation of thermal performance of semi-transparent PV technologies. Energy Build. 2016, 124, 19-34. [CrossRef]

158. Delisle, V.; Kummert, M. Cost-benefit analysis of integrating BIPV-T air systems into energy-efficient homes. Sol. Energy 2016, 136, 385-400. [CrossRef]

159. Meerbeek, B.W.; de Bakker, C.; de Kort, Y.A.W.; van Loenen, E.J.; Bergman, T. Automated blinds with light feedback to increase occupant satisfaction and energy saving. Build. Environ. 2016, 103, 70-85. [CrossRef]

160. Ibañez-Puy, M.; Bermejo-Busto, J.; Martín-Gómez, C.; Vidaurre-Arbizu, M.; Sacristán-Fernández, J.A. Thermoelectric cooling heating unit performance under real conditions. Appl. Energy 2017, 200, 303-314. [CrossRef]

161. Athienitis, A.K.; Barone, G.; Buonomano, A.; Palombo, A. Assessing active and passive effects of façade building integrated photovoltaics/thermal systems: Dynamic modelling and simulation. Appl. Energy 2018, 209, 355-382. [CrossRef]

162. Favoino, F.; Jin, Q.; Overend, M. Design and control optimisation of adaptive insulation systems for office buildings. Part 1: Adaptive technologies and simulation framework. Energy 2017, 127, 301-309. [CrossRef]

163. Jayathissa, P.; Luzzatto, M.; Schmidli, J.; Hofer, J.; Nagy, Z.; Schlueter, A. Optimising building net energy demand with dynamic BIPV shading. Appl. Energy 2017, 202, 726-735. [CrossRef]

164. Li, Z.; Peng, W.; Yujiao, H.; Wei, T.; Yong, S. Relationships between design parameters of see-through thin film photovoltaic facade and energy performance of office building in China cold zone. Energy Procedia 2018, 152, 401-406. [CrossRef]

165. Bellazzi, A.; Belussi, L.; Meroni, I. Estimation of the performance of a BIPV façade in working conditions through real monitoring and simulation. Energy Procedia 2018, 148, 479-486. [CrossRef]

166. Sorgato, M.J.; Schneider, K.; Rüther, R. Technical and economic evaluation of thin-film CdTe building-integrated photovoltaics (BIPV) replacing façade and rooftop materials in office buildings in a warm and sunny climate. Renew. Energy 2018, 118, 84-98. [CrossRef]

167. Gonçalves, J.E.; Montazeri, H.; van Hooff, T.; Saelens, D. Performance of building integrated photovoltaic facades: Impact of exterior convective heat transfer. Appl. Energy 2021, 287, 116538. [CrossRef] 
168. Zuazua-Ros, A.; Martín-Gómez, C.; Ibáñez-Puy, E.; Vidaurre-Arbizu, M.; Ibáñez-Puy, M. Design, assembly and energy performance of a ventilated active thermoelectric envelope module for heating. Energy Build. 2018, 176, 371-379. [CrossRef]

169. Luo, Y.; Zhang, L.; Liu, Z.; Wu, J.; Zhang, Y.; Wu, Z. Numerical evaluation on energy saving potential of a solar photovoltaic thermoelectric radiant wall system in cooling dominant climates. Energy 2018, 142, 384-399. [CrossRef]

170. Ciardiello, A.; Rosso, F.; Dell'Olmo, J.; Ciancio, V.; Ferrero, M.; Salata, F. Multi-objective approach to the optimization of shape and envelope in building energy design. Appl. Energy 2020, 280, 115984. [CrossRef]

171. Arregi, B.; Garay-Martinez, R.; Astudillo, J.; García, M.; Ramos, J.C. Experimental and numerical thermal performance assessment of a multi-layer building envelope component made of biocomposite materials. Energy Build. 2020, 214, 109846. [CrossRef]

172. Shakouri, M.; Ghadamian, H.; Noorpoor, A. Quasi-dynamic energy performance analysis of building integrated photovoltaic thermal double skin façade for middle eastern climate case. Appl. Therm. Eng. 2020, 179, 115724. [CrossRef]

173. Preet, S.; Sharma, M.K.; Mathur, J.; Chowdhury, A.; Mathur, S. Performance evaluation of photovoltaic double-skin facade with forced ventilation in the composite climate. J. Build. Eng. 2020, 32, 101733. [CrossRef]

174. Chen, X.; Huang, J.; Yang, H. Multi-criterion optimization of integrated photovoltaic facade with inter-building effects in diverse neighborhood densities. J. Clean. Prod. 2020, 248, 119269. [CrossRef]

175. Garraín, D.; Herrera, I.; Rodríguez-Serrano, I.; Lechón, Y.; Hepbasli, A.; Araz, M.; Biyik, E.; Yao, R.; Shahrestani, M.; Essah, E.; et al. Sustainability indicators of a naturally ventilated photovoltaic façade system. J. Clean. Prod. 2020, 266, 121946. [CrossRef]

176. Saretta, E.; Caputo, P.; Frontini, F. An integrated 3D GIS-based method for estimating the urban potential of BIPV retrofit of façades. Sustain. Cities Soc. 2020, 62, 102410. [CrossRef]

177. Gonçalves, J.E.; van Hooff, T.; Saelens, D. Understanding the behaviour of naturally-ventilated BIPV modules: A sensitivity analysis. Renew. Energy 2020, 161, 133-148. [CrossRef]

178. Gholami, H.; Røstvik, H.N. Economic analysis of BIPV systems as a building envelope material for building skins in Europe. Energy 2020, 204, 117931. [CrossRef]

179. Gholami, H.; Nils Røstvik, H.; Manoj Kumar, N.; Chopra, S.S. Lifecycle cost analysis (LCCA) of tailor-made building integrated photovoltaics (BIPV) façade: Solsmaragden case study in Norway. Sol. Energy 2020, 211, 488-502. [CrossRef]

180. Luong, D.L.; Nguyen, Q.T.; Pham, A.D.; Truong, Q.C.; Duong, M.Q. Building a Decision-Making Support Framework for Installing Solar Panels on Vertical Glazing Façades of the Building Based on the Life Cycle Assessment and Environmental Benefit Analysis. Energies 2020, 13, 2376. [CrossRef]

181. Miranda, R.; Babilio, E.; Singh, N.; Santos, F.; Fraternali, F. Mechanics of smart origami sunscreens with energy harvesting ability. Mech. Res. Commun. 2020, 105, 103503. [CrossRef]

182. Gonçalves, J.E.; van Hooff, T.; Saelens, D. Simulating building integrated photovoltaic facades: Comparison to experimental data and evaluation of modelling complexity. Appl. Energy 2021, 281, 116032. [CrossRef]

183. Tao, Y.; Zhang, H.; Zhang, L.; Zhang, G.; Tu, J.; Shi, L. Ventilation performance of a naturally ventilated double-skin façade in buildings. Renew. Energy 2021, 167, 184-198. [CrossRef]

184. Chen, Y.; Hua, H.; Wang, J.; Lund, P.D. Integrated performance analysis of a space heating system assisted by photovoltaic/thermal collectors and ground source heat pump for hotel and office building types. Renew. Energy 2021, 169, 925-934. [CrossRef]

185. Taveres-Cachat, E.; Favoino, F.; Loonen, R.; Goia, F. Ten questions concerning co-simulation for performance prediction of advanced building envelopes. Build. Environ. 2021, 191, 107570. [CrossRef]

186. Arnesano, M.; Pandarese, G.; Martarelli, M.; Naspi, F.; Gurunatha, K.L.; Sol, C.; Portnoi, M.; Ramirez, F.V.; Parkin, I.P.; Papakonstantinou, I.; et al. Optimization of the thermochromic glazing design for curtain wall buildings based on experimental measurements and dynamic simulation. Sol. Energy 2021, 216, 14-25. [CrossRef]

187. Catto Lucchino, E.; Gelesz, A.; Skeie, K.; Gennaro, G.; Reith, A.; Serra, V.; Goia, F. Modelling double skin façades (DSFs) in whole-building energy simulation tools: Validation and inter-software comparison of a mechanically ventilated single-story DSF. Build. Environ. 2021, 199, 107906. [CrossRef]

188. Rizi, R.A.; Eltaweel, A. A user detective adaptive facade towards improving visual and thermal comfort. J. Build. Eng. 2021, 33, 101554. [CrossRef]

189. Iommi, M. The mediterranean smart adaptive wall. An experimental design of a smart and adaptive facade module for the mediterranean climate. Energy Build. 2018, 158, 1450-1460. [CrossRef]

190. Jayathissa, P.; Jansen, M.; Heeren, N.; Nagy, Z.; Schlueter, A. Life cycle assessment of dynamic building integrated photovoltaics. Sol. Energy Mater. Sol. Cells 2016, 156, 75-82. [CrossRef]

191. Karasu, H.; Dincer, I. Life cycle assessment of integrated thermal energy storage systems in buildings: A case study in Canada. Energy Build. 2020, 217, 109940. [CrossRef] 